\title{
Implementing the competences-based and student-centered learning approach in Architectural Design Education. The case of the T MEDA Pilot Architectural Program at the Hashemite University (Jordan)
}

\author{
Ahmad A. S. Al Husban, Safa A. M. Al Husban, and Yamen Al Betawi*
}

doi: http://dx.doi.org/10.18543/tjhe-4(1)-2016pp43-98

\begin{abstract}
Higher educational systems become increasingly oriented towards the competences-based student-centered learning and outcome approach. Worldwide, these systems are focusing on the students as a whole: focusing on their dimensional, intellectual, professional, psychological, moral, and spiritual. This research was conducted in an attempt to answer the main research question: how can the architectural design courses be designed based on the required competences and how can the teaching, learning activities and assessment methods be structured and aligned in order to allow students to achieve and reach the intended learning outcomes? This research used a case study driven best practice research method to answer the research questions based on the T MEDA pilot architectural program that was implemented at the Hashemite University, Jordan. This research found that it is important for architectural education to adapt the students-centered learning method. Such approach increases the effectiveness of teaching and learning methods, enhances the design studio environment, and focuses on students' engagement to develop their design process and product. Moreover, this research found that using different assessment methods in architectural design courses help students to develop their learning outcomes; and inform teachers about the effectiveness of their teaching process. Furthermore, the involvement of students in assessment produces effective learning and enhances their design motivation.
\end{abstract}

Ahmad Abidrabbu Al Husban (alhusban2001@yahoo.com), D Des \& PhD in Architectural Design, is Assistant Professor in the Faculty of Engineering at The Hashemite University (Jordan).

Safa Abdullah Al Husban (safaalhusban@yahoo.com), D Des \& PhD in Architectural Design, is Assistant Professor in the Faculty of Engineering at Al al-Bayt University (Jordan).

Yamen N. Al Betawi (yamen_n@yahoo.com), PhD in City and Regional Planning, is Assistant Professor in the Faculty of Engineering at The Hashemite University (Jordan).

More details on the authors are provided at the end of this article.

The authors are grateful to The Hashemite University, Architectural Department for their consistent support into this research study. This work received no direct funding, but it depends on T MEDA pilot architectural program that was implemented at the Hashemite University (Jordan). Our thanks are also to all T MEDA project members. 
However, applying competences-based students-centered learning and outcome approach needs more time and staff to apply. Another problem is that some instructors resist changing to the new methods or approaches because they prefer to use their old and traditional systems. The application for this method at the first time needs intensive recourses, more time, and good cooperation between different instructors and course coordinator. However, within the time this method will be more useful and interesting for the teacher and more effective and formative for students. Finally, the development of architectural academic staff is needed to increase awareness of learning needs of all architectural students. This requires redesigning and aligning their curriculum and courses syllabus according to the requirements of new methods.

Keywords: Competences; meta-profile, intended learning outcome; teaching and learning activities; assessment methods; constructive alignment; students-center learning approach; architectural design.

\section{Introduction}

\section{I.1. Brief Background}

Higher education represents a crucial factor in innovations and human capital, which is the backbone for economic prosperity and social well-being in the 21 st century. ${ }^{1}$ Recently, higher educational systems become increasingly oriented towards the competences-based student-centered learning and outcome approach. ${ }^{2}$ Over worldwide, these systems are focusing on the students as a whole: focusing on their dimensional, intellectual, professional, psychological, moral, and spiritual. ${ }^{3}$ This focusing shift from the emphasis on the educational input to output; from the teacher-center learning to student-centered learning approach, and from focusing on teaching and instruction to focusing on learning..$^{4}$

${ }^{1}$ Karine Tremblay, Diane Lalancette, and Deborah Roseveare, Assessment of Higher Education Learning Outcomes: AHELO Feasibility Study Report - Volume 1 - Design and Implementation (Paris: Organisation for Economic Co-Operation and Development (OECD), 2012).

${ }^{2}$ CoRe, A Tuning Guide to Formulating Degree Program Profiles: Including Program Competences and Program Learning Outcomes (Bilbao: University of Deusto, Nuffic / TUNING Association, 2010).

${ }^{3}$ Aurelio Villa Sanches and Manual Poblete Ruiz, Competence-based Learning: A Proposal for the Assessment of Generic Competences (Bilbao: University of Deusto, 2008).

${ }^{4}$ CoRe, A Tuning Guide to Formulating Degree Program Profiles, 11.

${ }^{5}$ Chris Rust, "The Impact of Assessment on Student Learning: How Can the Research Literature Practically Help to Inform the Development of Departmental Assessment Strategies 
The students-center learning approach is a new way of thinking means the learner engages actively in learning under his/her responsibility and management. ${ }^{6}$ This approach requires using generic and specific competences and learning outcomes. It focuses on the requirements of the discipline and society in terms of preparing for citizenship and employability. ${ }^{7}$ It focuses also on what students do not what the teacher does. ${ }^{8}$ Using this approach requires the instructors to align the following primary elements of a course: competences and learning outcomes, content, teaching and learning activities, and assessments methods. ${ }^{9}$

This paradigm shift requires a change of the traditional academic staffs mind set. ${ }^{10}$ Additionally, the development of architectural academic staffs is needed to increase awareness of learning needs of all architectural students. They require redesigning and aligning their curriculum and courses syllabus according to the requirements of new methods. Therefore, this research presents a good practical example in architectural design educational area that links generic and specific competences, Meta profile, learning outcomes, teaching and learning activities, assessment methods, implementing, monitoring, evaluating and improving practice in architectural design education.

\section{I.2. Research Context}

In the context of architectural engineering, there is a paradigm shift occurring in the engineering curriculum and academic structure from objective-based/input-based education toward outcome-based education. ${ }^{11}$ Globally, new paradigm in higher education shifts from delivering lectures and providing students with the means to learn (teacher center learning or

and Learner-Centred Assessment Practices?," Active Learning in Higher Education (SAGE Publications) 145, no. 3 (2002): 145-158.

${ }^{6}$ David J. Nicol and Debra Macfarlane-Deck, "Formative assessment and self-regulated learning: Amodel and seven principles of good feedback practice," Studies in Higher Education 31, no. 2 (2006): 199-218.

7 Tuning, Introduction to Tuning (Bilbao: Tuning Academy, 2007).

${ }^{8}$ Duncan D Nulty, Curriculum Design (Griffith Institute, Griffith Institute for Higher Education, 2012).

${ }_{9}$ Stefan Popenici and Victoria Millar, Writing Learning Outcomes: A Practical Guide for Academics (The University of Melbourne, 2015).

${ }^{10}$ CoRe, A Tuning Guide to Formulating Degree Program Profiles, 19.

11 Tremblay, Lalancette, and Roseveare, Assessment of Higher Education Learning Outcomes, 36 . 
instruction paradigm) - towards a "learning paradigm" in which the emphasis is no longer on the means but on the end (student-centered learning or learning paradigm). ${ }^{12}$

This shift started in Europe in June 1999 when 29 European ministries of education decided to establish the European Higher Education Area (EHEA) by 2010 and decided to use the terms of learning outcomes and competences of their educational modules and programs. Now many courtiers are aligning their higher education with the Bologna process to facilitate description of qualifications, mutual recognition of degree, and student mobility. ${ }^{13}$

\section{I.3. Research Problem and Justification}

Higher education represents a crucial factor in innovations and human capital, which is a backbone of economic prosperity and social well-being in the 21 st century.${ }^{14}$ Recently, higher educational systems become increasingly oriented according to the competences-based student-centered learning and outcome approach. ${ }^{15},{ }^{16}$ Many faculties in Europe and US adopt the new learning philosophy; by contrast, Asia-Pacific reports many difficulties in implementing this effective reform. ${ }^{17}$

A good teaching method is a process to support learning activities and achieve the intended learning outcomes, which academic is using it spontaneously..$^{18}$ Some academics teach students without having much formal knowledge of how students learn. ${ }^{19}$ Additionally, not many writers apply theory to transform their practice in higher education..$^{20}$ Moreover, very

12 Ibid., 37.

${ }^{13}$ Ibid., 36.

${ }^{14}$ Ibid., 16.

${ }^{15}$ CoRe, A Tuning Guide to Formulating Degree Program Profiles, 25.

${ }_{16}$ Andy Gibbs, Declan Kennedy, and Anthony Vickers,'Learning Outcomes, Degree Profiles, Tuning Project and Competences," Journal of the European Higher Education Area 2012, no. 1: 72-88.

17 Tremblay, Lalancette, and Roseveare, Assessment of Higher Education Learning Outcomes, 37.

${ }_{18}$ John Biggs and Catherine Tang, Teaching for Quality Learning at University (Maidenhead: Open University Press/McGraw Hill, 2007).

${ }_{19}$ Heather Fry, Steve Ketteridge, and Stephanie Marshall, "Understanding student learning," in A Handbook for Teaching and Learning in Higher Education: Enhancing Academic Practice, ed. Heather Fry, Steve Ketteridge and Stephanie Marshall (New York: Routledge, 2009), 8-26.

${ }^{20}$ Biggs and Tang, Teaching for Quality Learning at University. 
few writers engage a reader to personal experience and open our eyes to the wonder approaches in higher education around us. ${ }^{21}$

There is a need for a formal strategy for teaching, learning and assessment in higher education to provide students with high quality of learning experience. This strategy aims to improve the physical learning environment and to develop life-long learning opportunity. ${ }^{22}$ Measuring the quality of higher education outcomes is needed to measure the effectiveness of education methods and to enhance the quality of higher education outcomes. ${ }^{23}$

The need for more systematic approach for supporting student learning becomes ever more important. ${ }^{24}$ The main principle to the implementing and developing of any learning, teaching, and assessment strategies is ensuring that we design, develop, implement, monitor, and assure that the best learning experience to all students, which support them to achieve the intended learning outcomes. ${ }^{25}$

Assessment and feedback are areas that students are least satisfied with. ${ }^{26}$ There has been little research about the assessment choice like offering assessment alternatives. ${ }^{27}$ Relatively little research has been done to find out academics' beliefs about assessment and yet this is fundamental if we are serious about making changes in our practice and persuading colleagues to do the same. ${ }^{28}$ Therefore, an alternative method of students' assessment is needed to develop an evidence base for development in the field of architectural design assessment. ${ }^{29}$

Assessment has become such a critical problem for architectural education. The architects and instructors do not pay intention to the outcome

${ }^{21}$ Ibid.

${ }^{22}$ GMIT, Code of Academic Policy No. 4: Learning, Teaching \& Assessment Strategy 2010 - 2015 (Galway-Mayo Institute of Technology, Dublin: Academic Council of GMIT, 2010).

23 Tremblay, Lalancette, and Roseveare, Assessment of Higher Education Learning Outcomes, 32.

${ }^{24}$ David Gosling, "Supporting student learning," in A Handbook for Teaching and Learning in Higher Education: Enhancing Academic Practice, ed. Heather Fry, Steve Ketteridge, and Stephanie Marshall, (New York: Routledge, 2009), 113-131.

${ }^{25}$ BC, Every learning matters: Balton College higher education: Learning. teaching and assessment strategy 2013-2016 (Bolton College, Bolton College, 2013).

${ }^{26}$ Lin Norton, "Assessing student learning," in A Handbook for Teaching and Learning in Higher Education: Enhancing Academic Practice, ed. Heather Fry, Steve Ketteridge and Stephanie Marshall (New York: Routledge, 2009), 132-149.

${ }^{27}$ Deborah Craddocka and Haydn Mathiasb, "Assessment options in higher education," Assessment \& Evaluation in Higher Education 34, no. 2 (2009): 127-140.

${ }^{28}$ Norton, "Assessing student learning," 133.

${ }^{29}$ Craddocka and Mathiasb, “Assessment options in higher education," 136. 
assessment from their own responsibility..$^{30}$ The instructors are still control over the formative assessment and feedback. The feedback is still seen as a transition process. ${ }^{31}$ There is a need to think about assessment methods in higher education. ${ }^{32}$ There is a need for formative assessment system to give students useful feedback about their work. ${ }^{33}$ To complement other aspects of learning and teaching, it is necessary to develop peer learning and assessment process. ${ }^{34}$

\section{I.4. Research Purpose}

The purpose of this research was to review, analyze, and synthesize the different related pieces from the higher education literature to explore, describe, summarize, and understand the holistic view of teaching and learning, program/curriculum design, generic and specific competences, intended learning outcomes, assessment and constructive alignment.

The further purpose was to present good practice research in architectural education based on the T-MEDA pilot program that implemented in the Hashemite University, Jordan. Additional purpose was to provide a model for aligning architectural learning outcomes for design 5 course with teaching and learning activities and assessment methods, which could be used by architectural design educators to design/redesign architectural courses and assist architectural colleagues to implement constructive alignment in their architectural education.

In addition, the intent was to increase the students' engagement level in the architectural learning activity; increase the academic orientation and attention to architectural design education, research, and studies; and eliminate the surface learning approach in architectural education and use deep approach to learning instead.

${ }^{30}$ James F. Pontuso and Saranna R. Thornton, "Is Outcomes Assessment Hurting Higher education?," The NEA Higher Education Journal Fall (2008): 61-70.

${ }_{31}$ Nicol and Macfarlane-Deck, "Formative assessment and self-regulated learning."

${ }^{32}$ Dorothy Spiller, Assessment matters: Self-assessment and peer assessment (The University of Waikato, Hamilton, New Zealand: Teaching Development Unit/Wāhanga Whakapakari Ako, 2012).

${ }^{33}$ Peter T. Knight, "Summative assessment in higher education: practices in disarray," Studies in Higher Education 27, no. 3 (2002): 275-286.

${ }^{34}$ David Boud, Ruth Cohen, and Jane Sampson, "Peer learning and assessment," Assessment and Evaluation in Higher Education 24, no. 4 (2000): 413-426. 


\section{I.5. Research Questions}

The research questions fall under two categories. The first and second research questions fall under the category of reviewing, analyzing, synthesizing, and exploring the different meaning and the relationships between different terminologies from the current higher education literature. The third, forth, and fifth research questions fall under the category of that which is unknown in the literature. Both of them were explored based on the implementation of the architectural T-MEDA pilot program at the Hashemite University, Jordan as a case study driven best practice method. However, the literature was reviewed and organized according to the research questions. The research questions were:

1. What do we mean by the following terminologies: teaching and learning,program/curriculum design, generic and specific competences, intended learning outcomes, assessment methods, and constructive alignment?

2. What are the relationships between all of the above terminologies?

3. What are the generic/specific competences and Meta-profile that are required for designing the architectural program at the Hashemite University, Jordan?

4. How can we design the course? How can the teaching, learning, and assessment activities in architectural design courses (design 5 as a case study) be best structured, organized, and aligned based on $\mathrm{T}$ MEDA project in order to allow students to achieve and reach the intended learning outcomes?

5. How can we implement the self and peer assessment methods in architectural design education?

\section{I.6. Research Hypothesis}

This research developed two hypotheses. The first hypothesis was that using the competences-based student-centered approach and constructive alignment in architectural design courses increases the effectiveness of teaching and learning methods; enhances its environment, and focuses on students' engagement and their successes. The second hypothesis was that using different assessment methods in architectural design courses helps 
students to develop their learning outcomes and informs teachers about the effectiveness of their teaching.

\section{I.7. Research Design (Methodology)}

This research used a case study driven best practice research method to answer the third, fourth, and fifth research questions and to report and describe the processes and the results of the T MEDA pilot architectural program that was implemented at the Hashemite University, Jordan: Design 5 course as a case study. This case study method used to analyze HU architectural program, its generic and specific competences, Meta profile, intended learning outcomes, assessment methods, constructive alignment, implementation process and procedures, evaluation for continuous development. By adopting a reflective approach, these issues are discussed and analyzed according to the authors experience in design education. This research adopted case study based approach to provide conceptual model of designing architectural design courses.

The case study is one of several ways of doing social science research.$^{35}$ It is a research approach or systematic inquiry into an event or a set of related events that is used to obtain, describe, report, interpret, explain, explore, and generate an in-depth, multi-faceted understanding of a complex issue, event or phenomenon of interest in its natural real-life settings in which it occurred $.^{36,},{ }^{37}$

The case study is a research strategy often categorized under the qualitative research method ${ }^{39}$ that provides tools for the researcher to study a phenomenon within their context. ${ }^{40}$ It can inform and report professional practice or evidence-informed decision-making ${ }^{41}$.

Many terminologies are used in scientific and professional literature like case study, case review, and case report: case study is evidence base 2014).

${ }^{35}$ Robert K. Yin, Case Study Research: Design and Methods, Vol. 5 (SAGE Publications,

${ }^{36}$ Sarah Crowe, Kathrin Cresswell, Ann Robertson, Guro Huby, Anthony Avery, and Aziz Sheikh, "The case study approach," BMC Medical Research Methodology 100, no. 11 (2011): 1-10.

${ }^{37}$ Pamela Baxter and Susan Jack, "Qualitative Case Study Methodology: Study Design and Implementation for Novice Researchers," The Qualitative Report 13, no. 4 (2008): 544-559.

38 Yin, Case Study Research: Design and Methods.

${ }^{39}$ Donna M. Zucker, How to Do Case Study Research. (College of Nursing, University of Massachusetts, Amherst: School of Nursing Faculty Publication Series, 2009).

${ }^{40}$ Baxter and Jack, "Qualitative Case Study Methodology."

${ }^{41}$ Ibid. 
professional applications; case review emphasizes on a critical reappraisal of a case; while case report refers to a summary of a case or to the document reporting a case. ${ }^{42}$

The case study research method is used when the focus of the study is to answer "how", "what", and "why" questions ${ }^{43}$ and when the researcher has little control over the variables. ${ }^{44}$

Data in case study research come from documentation, archival records, projects, longitudinal studies, in-depth interviews, direct observations, participant observation and physical artifacts..$^{45}$ The use of multiple sources of data (data triangulation) has been advocated as a way of increasing the internal validity. ${ }^{46}$

\section{I.8. Research Significance}

This research discussed the key concepts and principles of competences, learning and teaching, and assessment. It attempted to explain and measure the architectural design learning outcomes that achieve by students and learners; to develop the assessment strategies in architectural design education as a key part of the effective architectural curriculum development; to develop new and improve existing design students' assessment and feedback mechanisms; and to enhance the quality of teaching and learning through reflective practice.

Additionally this research tries to develop professional academic skills of architectural instructors' as teaching, learning, and assessment; to help the reader to build a practical foundation of knowledge that facilitate integration of the architectural design courses content, assessment, and delivery and how to design the architectural design courses. This research treats with each area separately to help the reader to consider all elements together in easy and systematic way to enhance personal practice.

This research will enhance and improve the validity and reliability of architectural design assessment methods. It will develop and promotes reflective and active learning techniques in design studio; enhance professional practice inside and outside design studio; facilitate innovations; develop quality and engaging environments for all architectural students and

\footnotetext{
${ }^{42}$ Zucker, How to Do Case Study Research.

${ }^{43}$ Baxter and Jack, "Qualitative Case Study Methodology."

${ }^{44}$ Yin, Case Study Research: Design and Methods.

${ }^{45}$ Zucker, How to Do Case Study Research.

${ }^{46}$ Crowe et al., "The case study approach."
} 
staff ${ }^{47}$ eliminate the subjectivity in assessment and increase objectivity; and enhance the quality of higher education outcomes.

\section{Literature Review}

\section{II.1. What Does Teaching and Learning Mean?}

Education is something you create for yourself in order to receive a career. ${ }^{48}$ Teaching can be seen as a process of transmitting the course content to the students through different methods, assessment, projects, lectures, tutorials, and exams. ${ }^{49}$ Biggs, as cited in Stefani, 2009, mentioned the critical components of teaching as follow: the curriculum, the teaching methods and strategies, the assessment and evaluation processes, and the education environment. ${ }^{50}$

Learning is seen as a constructive act of the learner, ${ }^{51}$ which requires knowledge, skills, and values.$^{52}{ }^{53}$ Learning is a process whereby students effectively construct their own knowledge and skills ${ }^{54}$ from what they do and think.$^{55}$ Learning includes understanding materials of subject area, developing subject-specific and general skills, reflecting and thinking strategically. ${ }^{56}$

Learning is a process that involves changing in knowledge, skills, believes, and attitudes ${ }^{57}$ and it aims to achieve learning outcomes. ${ }^{58}$ The literature

${ }^{47}$ GMIT, Code of Academic Policy No. 4: Learning, Teaching \& Assessment Strategy 2010 - 2015 (Galway-Mayo Institute of Technology, Dublin: Academic Council of GMIT, 2010).

48 Ibid.

49 Biggs and Tang, Teaching for Quality Learning at University.

${ }^{50}$ Lorraine Stefani, "Planning teaching and learning: Curriculum design and development," in A Handbook for Teaching and Learning in Higher Education: Enhancing Academic Practice, ed. by Heather Fry, Steve Ketteridge, and Stephanie Marshall (New York: Routledge, 2009), 40-57.

${ }^{51}$ Katrien Struyven, Filip Dochy, and Steven Janssens, "Students' perceptions about assessment in higher education: A review," Assessment \& Evaluation in Higher Education 30, no. 4 (2005): 331-347.

${ }^{52}$ Liesel Knaack, Enhancing your programs and cources through alighed learning outcomes (Vancouver Island University, Vancouve: Centre for Innovation and Excellence in Learning, 2015).

${ }_{53}$ Marian McCarthy, "Aligning Learning Outcomes, Learning Activities and Assessment," Seminario Internacional SCT, (Pucón: Marian McCarthy, Augest 31, 2011).

${ }_{54}$ Nicol and Macfarlane-Deck, "Formative assessment and self-regulated learning."

55 Susan A. Ambrose, Michael W. Bridges, Michele DiPietro, Marsha C. Lovett, Marie K. Norman, and RICHARD E. MAYER, How Learning Works: Seven Research-Based Principles for Smart Teaching (San Francisco: John Wiley \& Sons, Inc., 2010).

${ }^{56}$ Knight, "Summative assessment in higher education: practices in disarray."

${ }^{57}$ Ambrose et al., How Learning Work.

${ }^{58}$ Raquel M. Crespo, Jad Najjar, Michael Derntl, Derick Leony, Susanne Neumann, Petra Oberhuemer, Michael Totschnig, Bernd Simon, Israel Gutiérrez, Carlos Delgado Kloos, 
revealed that learning is essentially: constructive, self- regulated, cumulative, goal- oriented, collaborative, situated, and individually different ${ }^{59}$ Learning development is the learners' process to develop their thinking ability, their knowledge, their self awareness and understanding, and become critical thinkers. It also refers to the process that are designed to help them do so. ${ }^{60}$

There are two different approaches to learning. The first is the deep learning approach, which leads from an intention to understand and to active conceptual analysis. In this approach, learner engages in a more active dialogue with the task. The second is the surfaces approach, which the learner tends to complete learning task with little personal engagement. ${ }^{61}{ }^{62}$

Student use the deep approach to understand the interested ideas in their studies and they are looking for pattern, principles, and meanings in the text. This approach leads to higher quality learning outcomes ${ }^{63}$. Students in this approach focus on what author means, organize and structure the content, and consider the reading as an important source of learning. ${ }^{64}$

Students use the surface approach to cope with the task requirements with little personal engagements and aim to understand the course materials. Students who using this method do not grasp the overall meanings of studies; have poor quality learning outcomes; and they develop limited understanding of the course materials. ${ }^{65}$ Students in this approach focus on the memorizing facts and feel differentiate between evidence and information. ${ }^{66}$

There is no one learning and teaching approach that fits with all students. Different learning strategies can employ to support all learners. ${ }^{67}$ Planning of multiple approaches and strategies to learning for each student is a fundamental role and aspect of academic staff. ${ }^{68}$ The effective teaching and

\footnotetext{
"Aligning Assessment with Learning Outcomes in Outcome-based Education." EEE Education Engineering (IEEE EDUCON Education Engineering, 2010), 1-8.

${ }^{59}$ Struyven, Dochy, and Janssens, "Students' perceptions about assessment in higher education."

${ }^{60}$ Gosling, "Supporting student learning."

${ }^{61}$ Struyven, Dochy, and Janssens, "Students' perceptions about assessment in higher education."

${ }^{62}$ Sue Bloxham and Pete Boyd. Developing Effective Assessment in Higher Education: a practical guide (England: McGraw-Hill House, 2007).

${ }^{63}$ Ibid., 17.

${ }^{64}$ Nulty, Curriculum Design.

${ }_{65}$ Bloxham and Boyd, Developing Effective Assessment in Higher Education, 17.

${ }^{66}$ Nulty, Curriculum Design.

${ }^{67} \mathrm{~B} \& \mathrm{FC}$, Learning, teaching, and assessment strategies guide (Blackpool and The Fylde College, 2013).

${ }^{68}$ Stefani, "Planning teaching and learning: Curriculum design and development."
} 
learning practices are the most important to create high quality experience and critical to learner success. It requires supportive and aspiration environment and use of educational resources to provide students with high quality of learning and teaching; to provide and develop students' skills and enhance their effective employability; improve the students' experience; improve the pedagogy; and to bring successful achievements. ${ }^{69}$ Therefore, the learning and teaching activities require students to apply, invent, generate new ideas, and solve the design problems. $.^{70},^{71}$

\section{II.2. Program Design or Curriculum Design}

The new agenda for universities is to sell education and to provide for market needs. ${ }^{72}$ Students have to pay higher fees to be well taught and will enhance their employment prospects. ${ }^{73}$ Therefore, many different terminologies are used to refer to degree program and the unit courses like programs, courses, units, modules or subjects. ${ }^{74}$ Program means a set of courses that lead to a certain degree, which encompasses from core curriculum and optional courses to reflect the institution values, goals and missions that provide professional experience and skills for students. ${ }^{75}$

The curriculum is a comprehensive plan for educational program. ${ }^{76} \mathrm{It}$ provides specific plan for learning and teaching to achieve the intended learning outcomes. ${ }^{77},{ }^{78}$ It uses to refer to focus on study that containing various designed courses to achieve the required proficiency and qualifications ${ }^{79}$ It is a

${ }^{69} \mathrm{~B} \& \mathrm{FC}$, Learning, teaching, and assessment strategies guide.

${ }^{70}$ Biggs and Tang, Teaching for Quality Learning at University.

${ }^{71}$ Gibbs, Kennedy, and Vickers, "Learning Outcomes, Degree Profiles, Tuning Project and Competences."

${ }^{72}$ Biggs and Tang, Teaching for Quality Learning at University. 3.

73 Ibid., 2.

${ }^{74}$ Ibid., xviii.

75 SAQA, The National Qualifications Framework: Curriculum Development (A publication of the South African Qualifications Authority, 2000).

${ }^{76}$ Irma Dolores Núñez y. Bodega, "From curriculum to syllabus design: The different stages to design a program." MEMORIAS DEL III FORO NACIONAL DE ESTUDIOS EN LENGUAS 13, no. 3 (2007): 275-290.

77 Ibid.

${ }^{78}$ Iftikhar Uddin Khwaja, Shahnaz Akhtar, and Abida Mirza, Module III: Currculum Developmet, Assessment and Evaluation: Professional Competency Enhancement Program for Teachers (PCEPT) (Islamabad: National Academy of Higher Education (NAHE): Learning Innovation Division and Higher Education Commission (HEC), 2014).

${ }^{79}$ Ibid. 
structure document refers to all aspects of teaching and learning activities, which take place in learning institution. ${ }^{80}$

The curriculum should involve the educational content: what should be learned and how should it be organized.$^{81}$ It should encompass the intended learning outcomes, aims and objectives, philosophy, standard setting, teaching and learning methods, value, skills, attitudes, content, the relationships between teachers and learners, assessment methods, evaluation, and how all of these are organized together to provide professional experience. $.^{82},{ }^{83}{ }^{84}$ It represents what students should know and be able to do and support teachers in knowing how to achieve these goals..$^{85}$

The curriculum design is purposeful to improve students' learning. It is deliberate goals that involves using an explicit process and identifies what will be done, by whom, and when to attain the intended learning outcomes ${ }^{86}{ }^{87} \mathrm{It}$ is a complex mechanism that focuses on the skills and competences, which are important for employees and employability. ${ }^{88}$ It is a systematic and creative procedure that operates on many levels to provide specific learning knowledge, develop skills, attitudes, values under specific academic program. ${ }^{89}, 90,91$

\section{II.3. Generic and Specific Competences}

Competences mean the proven ability to use knowledge and skills in work, professional and personal practice..$^{92}$ They have many interchangeable terms like capacity, attribute, ability, capability, and skills that enable

${ }^{80}$ Bodega, "From curriculum to syllabus design: The different stages to design a program."

${ }^{81}$ Stephen Petrina, Curriculum and Instruction Design: Advanced Teaching Methods for the Technology Classroom (University of British Columbia, Canada, 2007).

${ }^{82}$ Ibid.

${ }^{83}$ Bodega, "From curriculum to syllabus design: The different stages to design a program."

${ }^{84}$ SAQA, The National Qualifications Framework: Curriculum Development.

${ }^{85}$ Bodega, "From curriculum to syllabus design: The different stages to design a program."

${ }^{86}$ AAAS, Designs for Science Literacy (New York: American Association for the Advancement of Science: Oxford University Press, Inc., 2000).

${ }^{87}$ UNISA, curriculum Policy (University of South Africa (UNISA), 2010).

${ }_{88}$ Joseph Kessels, and Tjeerd Plomp, "A relational approach to curriculum design." Verschenen in Journal of Curriculum Studies 31, no. 6 (1999): 679-709.

${ }^{89}$ Khwaja, Akhtar, and Mirza, Module III: Currculum Developmet, Assessment and Evaluation.

${ }^{90}$ Bodega, "From curriculum to syllabus design: The different stages to design a program."

91 AAAS, Designs for Science Literacy.

${ }_{92}$ Crespo et al., "Aligning Assessment with Learning Outcomes in Outcome-based Education." 
learners to think and act in different area of activities (put the knowledge into practice). ${ }^{93}$ They are a part of the educational process and they mean to building of the knowledge. They represent dynamic combination between knowledge, understanding, attitude, abilities, roles, and responsibilities. ${ }^{94}$ Competences are necessary for today's world ${ }^{95}$ to obtain a job, gaining promotion in labor market, and to enhance the employment opportunities. ${ }^{96}$

Competences are the cornerstone in the teaching-learning process. ${ }^{97}$ They can be described as reference point to the curriculum design and evaluation. Therefore, the competences are not linked to one course, but they can be developed and evaluated during the total learning process of a study program..$^{98}$ The program is structured and specified in terms of generic and specific competence. ${ }^{99}$

Generic competences are common competences that can be identified in different degree programs. ${ }^{100}$ Generic competences are multifunctional, multidimensional, transversal, instrumental, interpersonal, and systematic competences that pertaining to each profession. They aim to provide students with scientific technical knowledge and enable them to apply such knowledge in different context. ${ }^{101}$ While, specific competences are intimately related to specific knowledge of an area of study..$^{102}$

\section{II.4. Degree Profile}

The degree profile is a document containing essential information about specific degree program. The profile specifies the subject areas and indicates the special aims and features that distinguish a program form other similar programs. It is described in the terms of the competences and learning

93 Tuning, Introduction to Tuning.

${ }^{94}$ Sanches and Ruiz, Competence-based Learning.

95 Ibid.

${ }^{96}$ L. Arnau-Sabatés, M.T Marzo, M. Jariot, and J. Sala-Roca, "Learning basic employability competence: a challenge for the active labour insertion of adolescents in residential care in their transition to adulthood," European Journal of 17, no. 2 (2013): 252-265.

97 Sanches and Ruiz, Competence-based Learning.

98 Tuning, Introduction to Tuning.

99 Sanches and Ruiz, Competence-based Learning.

100 Tuning, Introduction to Tuning.

101 Sanches and Ruiz, Competence-based Learning.

102 Tuning, Introduction to Tuning. 
outcomes ${ }^{103}$ and consists from the merging between generic and specificsubject competences. ${ }^{104}$

\section{II.5. Intended Learning Outcomes (ILOs)}

Intended learning outcomes (ILOs) means what students should able to know, understand, demonstrate, acquire, perform, and/or feel after the completion the learning process of the course or programme. The ILOs are performance oriented to measure the anticipated students' achievement. They rely and emphasis on the student-centered learning approach and on the learner's ability to do something. They inform the teacher about the content of the teaching (knowledge and skills), teaching strategies and learning activities/tasks; describe what the students should learn; and used to develop assessment tasks and criteria. ${ }^{105},{ }^{106},{ }^{107},{ }^{108},{ }^{109},{ }^{110},{ }^{111},{ }^{112}$ They are often specific, precise, and measurable. ${ }^{113}$

An intended learning outcome approach has only recently begun to be used in many countries ${ }^{114}$ and has an international interest. ${ }^{115}$ It is students oriented ${ }^{116}$ and considered as an important factor to measure the institution performance. ${ }^{117}$ The development, practical use and understanding of learning outcomes is crucial to the success the degree supplement, recognition,

${ }^{103}$ CoRe, A Tuning Guide to Formulating Degree Program Profiles, 20.

104 Tuning, Introduction to Tuning.

105 UTAS, Guideline for good assessment prcitces (University of Tasmania, University of Tasmania Assessment, 2011).

${ }^{106}$ Knaack, Enhancing your programs and cources through alighed learning outcomes.

107 McCarthy, "Aligning Learning Outcomes, Learning Activities and Assessment."

${ }^{108}$ Lori Goff et al., learning Outcomes Assessment: A Practitioner's Handbook (Ontario: Higher Education Quality Council of Ontario (HEQCO), 2014).

${ }^{109}$ Stefani, "Planning teaching and learning: Curriculum design and development."

110 AAAS, Designs for Science Literacy.

111 Popenici and Millar, Writing Learning Outcomes.

${ }^{112}$ Steve Y. W. LAM, "Outcome-Based Approach to Teaching, Learning and Assessment in Geomatics Higher Education: the Hong Kong Experience." Good Educational Practices, 2009: 1-10.

${ }_{113}$ Knaack, Enhancing your programs and cources through alighed learning outcomes.

114 Gibbs, Kennedy, and Vickers, "Learning Outcomes, Degree Profiles, Tuning Project and Competences."

${ }^{115}$ Goff, et al., learning Outcomes Assessment.

116 Nulty, Curriculum Design.

117 Tremblay, Lalancette, and Roseveare, Assessment of Higher Education Learning Outcomes. 
and the degree qualification profile and quality assurance. ${ }^{118}$ All educational activities should be related to the intended learning outcomes of the course in order to help students in achieving ILOs at the end of the course. ${ }^{119}$

The intended learning outcomes approach becomes a common language between educators, ${ }^{120}$ which covers knowledge, skills, and competences. ${ }^{121}$ It brings clarity, precision, and transparency to teaching practice and assessment. ${ }^{122}$ Therefore, the ILOs are linked to assessment and evaluation methods along with the teaching and learning strategies ${ }^{123}$ as a basis for measuring and reporting students' achievement ${ }^{124},{ }^{125}$ and describing the expected level that achieved from the intended learning outcomes in order to attain certain grades. ${ }^{126}$

The intended learning outcomes depend upon two factors: the assessment units that are designed to enable the students to demonstrate their understanding. The second is the students' learning process to fulfilling the course outcomes. ${ }^{127}$ The learning outcome should be defined before teaching take place. ${ }^{128}$ Additionally, the level of understanding of learning and teaching activities should be clearly specified and understood by students from the beginning. ${ }^{129}$ These steps are to improve the effectiveness and increase the quality of the program ${ }^{130},{ }^{131}$ and to create a dynamic equilibrium between teaching strategies, appropriate activities,

118 Ibid., 36.

119 Crespo et al., "Aligning Assessment with Learning Outcomes in Outcome-based Education."

${ }^{120}$ Gibbs, Kennedy, and Vickers, "Learning Outcomes, Degree Profiles, Tuning Project and Competences."

${ }^{121}$ Crespo et al., "Aligning Assessment with Learning Outcomes in Outcome-based Education."

${ }^{122}$ Popenici and Millar, Writing Learning Outcomes.

${ }^{123}$ Knaack, Enhancing your programs and cources through alighed learning outcomes.

124 Popenici and Millar, Writing Learning Outcomes.

125 Goff et al., learning Outcomes Assessment.

126 UTAS, Guideline for good assessment prcitces.

127 Richard Hall, "Aligning learning, teaching and assessment using the web: An evaluation of pedagogic approaches." British Journal of Educational Technology (Blackwell Publishers Ltd) 33, no. 2 (2002): 149-158.

128 John Biggs, "Constructive alignment in university teaching." HERDSA Review of Higher Education, no. 1 (2014): 5-22.

${ }^{129}$ Clever Ndebele and Cosmas Maphosa, "Exploring the Assessment Terrain in Higher Education: Possibilities and Threats: A Concept Paper." Journal of Social Science 35, no. 2 (2013): 149-158.

${ }^{130}$ Goff et al., learning Outcomes Assessment.

131 John B. Biggs, “Aligning teaching for constructing learning." FOCUS 16, no. 1 (2008): 1-3. 
and learning outcomes. ${ }^{132},{ }^{133}$ Clear and realistic learning outcomes provide students with a good guide about what has to be learned, how to teach, and what learning opportunities to provide. ${ }^{134}$

Intended learning outcomes (ILOs) are not curriculum objectives as before. ${ }^{135}$ Learning outcomes describe what students are able to do after the completion of the process of learning; while learning objectives are written from the instructors' perspectives in terms of their teaching intentions and focused on what content they attend to achieve different tasks. ${ }^{136},{ }^{137},{ }^{138}$

There is no limited number of the intended learning outcomes for a subject or a course. It depends on the level of study. However, it is important to have an adequate number to secure adequate information for comprehensive assessment and to provide information for improvement in teaching and course design. It is important to choose a balance number of intended learning outcome to be suitable with your overall aims and the level of study. ${ }^{139}$

In conclusion, Outcomes-based teaching and learning is concerned with more effective teaching and assessment at the course and program level. ${ }^{140} \mathrm{It}$ depends on constructive alignment and relies on these questions: what the students know and able to demonstrate after teaching new knowledge and to what standard at the course and/or program level? How the learning activity can apply to help them in achieving the outcomes? In addition, how do the instructors assess them to measure their achievements? ${ }^{141},{ }^{142}$

\section{II.6. Assessment}

Assessment is a very complex task ${ }^{143}$ and skill-based. ${ }^{144}$ It is a set of processes that measure the outcome of students' learning in terms of

${ }^{132}$ McCarthy, "Aligning Learning Outcomes, Learning Activities and Assessment,"

${ }^{133}$ Hall, "Aligning learning, teaching and assessment using the web."

134 Ndebele and Maphosa, "Exploring the Assessment Terrain in Higher Education," 152.

${ }_{135}$ Biggs and Tang, Teaching for Quality Learning at University.

${ }_{136}$ Popenici and Millar, Writing Learning Outcomes.

137 Knaack, Enhancing your programs and cources through alighed learning outcomes.

138 AAAS, Designs for Science Literacy.

139 Popenici and Millar, Writing Learning Outcomes.

${ }^{140}$ Biggs and Tang, Teaching for Quality Learning at University, 3.

${ }^{141}$ Ibid.

${ }^{142}$ Goff et al., Learning Outcomes Assessment.

${ }^{143}$ Khwaja, Akhtar, and Mirza, Module III: Currculum Developmet, Assessment and Evaluation.

144 Biggs and Tang, Teaching for Quality Learning at University. 
knowledge acquired, understanding developed and skills or abilities gained. ${ }^{145}$ Assessment is recognized as learning activity that designed to help students to focus on learning. ${ }^{146}$ Assessment is part from teaching and learning process aims to measure and monitor to what extent the intended learning outcomes and objectives achieved. ${ }^{147}$

Assessment is a process of ensuring if the students have leaned what they have been taught and what students are able to do or demonstrate. ${ }^{148},{ }^{149}$ The assessment tasks inform us how these students use their accumulated knowledge academically in their professional practice in appropriate ways. ${ }^{150}{ }^{151}$ Assessment methods need to be clear from earliest stages of course. It should be fully aligned with all other aspects of course design. ${ }^{152}$

Assessment involves two main pillars: process (how student learn) and subject material (what student learn). ${ }^{153}$ Assessment is an integral component of learning and teaching. It includes all process employed by instructors to make judgments about students' achievements over the course of study. ${ }^{154}$ This can be achieved: when there is a clear alignment between intended learning outcomes, the students' learning experience, and the assessment tasks; when the students fully understand the assessment process; when there is a clear assessment requirement; and when the assessment tasks designed to assess the capacity to analysis and synthesis design information and concepts. ${ }^{155}$

The nature of particular learning and assessment task determines and influences the students' approach to learning whether deep or surface approach. ${ }^{156},{ }^{157}$ Appropriate assessments can encourage students to adapt the

${ }^{145}$ UU, Assessment Handbook (Ulster University, 2015).

146 David Boud, Assessment 2020: Seven propositions for assessment reform in higher education (Sydney: Sydney: Australian Learning and Teaching, 2010).

${ }^{147}$ Ndebele, and Maphosa, "Exploring the Assessment Terrain in Higher Education."

148 AAAS, Designs for Science Literacy.

149 Ndebele, and Maphosa, "Exploring the Assessment Terrain in Higher Education," 152.

${ }^{150}$ Biggs and Tang, Teaching for Quality Learning at University.

${ }^{151}$ Gibbs, Kennedy, and Vickers, "Learning Outcomes, Degree Profiles, Tuning Project and Competences."

152 Boud, Assessment 2020: Seven propositions for assessment reform in higher education.

153 UU, Assessment Handbook.

${ }^{154}$ UTAS, Guideline for good assessment prcitces.

155 Ibid., 1.

${ }^{156}$ Ndebele and Maphosa, "Exploring the Assessment Terrain in Higher Education."

${ }^{157}$ Struyven, Dochy, and Janssens, "Students' perceptions about assessment in higher education." 
deep learning approach. ${ }^{158}$ It plays a critical role of how students learn and what they choose to learn. ${ }^{159}$ It is a tool of learning ${ }^{160}$ that involves and identifies clear, valid and appropriate students' learning outcomes. ${ }^{161}$ It shapes the students' experience and influences their behavior more than the received teaching. ${ }^{162}$ Because the students only learn what they think they will be assessed on, the students want to know what we expect from them, how they will be assessed, and what the mark/level of achievement means; how can we recognize their achievements? ${ }^{163}$

The affective assessment should link directly to the intended learning outcomes and focus upon skills and their transfer. ${ }^{164}{ }^{165}$ All assessment includes two main aspects: making decisions about the standards of performance expected and then making judgments about the quality of the performance in relation to these standards. ${ }^{166}$ The assessment issues are the focus when the colleagues from different schools meet each other. ${ }^{167}$ Assessment practices are a complex and join activity between teacher and learner that improve the learner achievements and their capacity to learn how to learn. ${ }^{168}$ Therefore, assessment practices should be reviewed in the light of employer perception and of graduates. ${ }^{169}$

The purposes of assessment are to enhance, improve, measure, and evaluate the students' knowledge, and their engagement in learning; enhance the quality of the students' learning achievements ${ }^{170},{ }^{171}$ through complete designed formal tasks; determine what students' learn; diagnose students'

158 Bloxham and Boyd, Developing Effective Assessment in Higher Education: a practical guide, 19.

159 Ndebele and Maphosa, "Exploring the Assessment Terrain in Higher Education."

160 Sluijsmans D., F. Dochy, and G. Moerkerke, the use of self-, peer-, and co-assessment in higher education: A review of literature (Open University of Netherlands, Otec, 1998).

161 AAAS, Designs for Science Literacy.

162 Bloxham and Boyd, Developing Effective Assessment in Higher Education: a practical guide.

${ }^{163}$ Ndebele and Maphosa, "Exploring the Assessment Terrain in Higher Education."

164 UU, Assessment Handbook.

165 Bloxham and Boyd, Developing Effective Assessment in Higher Education: a practical guide.

${ }^{166}$ Spiller, Assessment matters:Self-assessment and peer assessment.

167 Pontuso and Thornton, "Is Outcomes Assessment Hurting Higher education?".

168 B\&FC, Learning, teaching, and assessment strategies guide.

169 Boud, Assessment 2020: Seven propositions for assessment reform in higher education.

170 Sally Brown, "Assessment for learning." Learning and Teaching in Higher Education, no. 1 (2004): 81-89.

171 Boud, Assessment 2020: Seven propositions for assessment reform in higher education. 
strengths and weaknesses; give students feedback on their performance and progress. ${ }^{172}$

Additionally, assessment aims to provide quality assurance evidence and encourage students to develop their knowledge, skills, and predispositions to underpin lifelong learning. ${ }^{173},{ }^{174}$ Additionally, it aims to provide a marks and grades, enable the public to know that the student has got an appropriate level of education and achievements; ${ }^{175}$ enable staff to evaluate the effectiveness of their teaching methods; ${ }^{176}$ define the next learning goals; and help the students to achieve the intended learning outcomes. ${ }^{177}$

Assessment is driven the learning. It is integral part of teaching and learning strategies. ${ }^{178}$ It serves as social and academic purpose that encompasses the gathering of evidence of the students' learning achievements through assignments, tests, projects, and examinations. ${ }^{179}$ Assessment tasks help students to achieve learning outcomes and supports learning. ${ }^{180},{ }^{181} \mathrm{It}$ gives students feedback about their work to understand what is good about their work and how they can develop it in future; and about where they have gone wrong and what they need to do to improve. ${ }^{182},{ }^{183}$ Assessment has significance influence on students' experience in higher education. The improving assessment practices have huge impact on the quality of learning. ${ }^{184}$

If we want to change the way that our students learn and the content of what they learn, the most effective way is to change the way we assess them. ${ }^{185}$ (Nicol and Macfarlane-Deck 2006) found that there are many considerable evidence to show that the feedback leads to generate learning and produces significance achievement benefits, knowledge and skills across all education areas.

172 Ndebele and Maphosa, "Exploring the Assessment Terrain in Higher Education."

173 Bloxham and Boyd, Developing Effective Assessment in Higher Education: a practical guide.

174 ASCC, ASCC alignment and assessment of students learning outcomes (SLOs): Training manual (California: Accrediting Commission for Community Junior College, 2008).

175 Norton, "Assessing student learning."

176 UU, Assessment Handbook.

177 B\&FC, Learning, teaching, and assessment strategies guide.

178 Nulty, Curriculum Design.

179 Ndebele and Maphosa, "Exploring the Assessment Terrain in Higher Education."

${ }^{180}$ Norton, "Assessing student learning."

${ }^{181}$ Brown, "Assessment for learning."

182 Ibid.

${ }^{183}$ Norton, "Assessing student learning."

184 Boud, Assessment 2020: Seven propositions for assessment reform in higher education.

185 Norton, “Assessing student learning," 134. 


\section{II.6.1. Types of assessment}

There are two types of assessment: summative and formative assessment. ${ }^{186}$ The summative assessment is a kind of judgment, which contributes to the overall grade of the degree classification that summarizes the student learning at end of program (sum-up of student achievements) ${ }^{187},{ }^{188}$ to provide achievement certificate. ${ }^{189}$ The summative assessment is carried out at the end of a subject or after the conclusion of a major topic. ${ }^{190}$ It provides a measure of achievement made in respect of a student's performance in relation to the intended learning outcomes of the module and/or program of study. ${ }^{191}$

While the formative assessment is a kind of purpose that enables students to see how well they are progressing and gives them feedback. ${ }^{192}$, ${ }^{193}$ Formative feedback is crucial. It needs to be comprehensive, detailed, fair, challenging and supportive, meaningful to individual. ${ }^{194}$ The formative assessment and feedback processes help students to become self-learner and control over their own learning. It used to empower students as self-regulated learning. ${ }^{195}$

The main aims of formative assessments are to provide students with feedback on their progress and performance to recognize their achievement ${ }^{196},{ }^{197}$ and to increase opportunities to improve their work and accelerated learning. ${ }^{198},{ }^{199}$ Additionally, it aims to identify learning needs and adjust teaching appropriately; to meet divers students' needs; to achieve a greater equity of student outcomes; to hold schools accountable for student achievement; to identify areas for improvement and promote effective evaluation throughout education systems; to meeting the goals of lifelong learning; and to promote high quality of education. ${ }^{200}$

\footnotetext{
${ }^{186} \mathrm{~B} \& \mathrm{FC}$, Learning, teaching, and assessment strategies guide.

${ }^{187}$ McCarthy, "Aligning Learning Outcomes, Learning Activities and Assessment."

188 Norton, “Assessing student learning," 137.

${ }^{189}$ Craddocka and Mathiasb, "Assessment options in higher education."

190 Brown, "Assessment for learning."

191 UU, Assessment Handbook.

192 Norton, "Assessing student learning," 137.

${ }^{193}$ Craddocka and Mathiasb, "Assessment options in higher education," 133.

194 Brown, "Assessment for learning."

195 Nicol and Macfarlane-Deck, "Formative assessment and self-regulated learning."

196 UU, Assessment Handbook.

197 Knight, "Summative assessment in higher education: practices in disarray."

198 Ndebele and Maphosa, "Exploring the Assessment Terrain in Higher Education," 153.

199 Nicol and Macfarlane-Deck, "Formative assessment and self-regulated learning," 129.

${ }^{200}$ CERI, assessment for learning - the case fgor formative assessment (OECD/CERI International Conference, 2008).
} 


\section{II.6.2. Different assessment methods}

Assessment needs to take place at the very end of the process. ${ }^{201}$ Applying different assessment methods is a good practice to assess different kinds of learning process. ${ }^{202}$ These have to be used in order to cope with large number of students, their gender, race, ethnicity, ability, and religion, education, professional background etc. ${ }^{203}$ They measure the level of students' achievements from intended learning outcomes. Additionally, they should meet the following principles: validity, fairness, reliability, and rigor. ${ }^{204}$

Self-assessment is process that students evaluate and assesses the quality of their work and learning, judge the degree to which they meet the course intended learning outcomes, and define the strength and weakness in their design work. ${ }^{205}$ The students' role in self-assessment is a proactive role. Students are assessing their own work and generating their own feedback. ${ }^{206}$

Self-assessment encourages students to become independent learning; helps them to critique their own; defines the weakness and strengthen on it; becomes responsible for their own education. ${ }^{207}$ Self-assessment increases and encourages the students' active participation and engaging actively in the learning process. ${ }^{208}$ The students in self-assessment procedure need to know the purpose, the criteria, and process of assessments. ${ }^{209}$

Peer-assessment refers to a process whereby the groups of individuals rate their peers. ${ }^{210}$ It means that students provide feedback or grades to other students about the quality of their work. ${ }^{211}$ The students learn with and from each other as group focus. ${ }^{212}$ Students accept criticism from peers and the language used by peers easier to understand than instructors. ${ }^{213}$ Peer assessment is often seen as unfair because students do not trust each other's

201 Brown, "Assessment for learning."

${ }^{202}$ Craddocka and Mathiasb, "Assessment options in higher education."

${ }^{203}$ Ndebele and Maphosa, "Exploring the Assessment Terrain in Higher Education," 153.

${ }^{204}$ UU, Assessment Handbook, 4-5.

${ }^{205}$ Spiller, Assessment matters:Self-assessment and peer assessment, 3.

${ }^{206}$ Nicol and Macfarlane-Deck, "Formative assessment and self-regulated learning."

${ }^{207}$ Ndebele and Maphosa, "Exploring the Assessment Terrain in Higher Education," 153.

208 Sluijsmans, Dochy, and Moerkerke, the use of self-, peer-, and co-assessment in higher education.

${ }^{209}$ Spiller, Assessment matters:Self-assessment and peer assessment.

210 Sluijsmans Dochy and Moerkerke, the use of self-, peer-, and co-assessment in higher education.

${ }^{211}$ Spiller, Assessment matters:Self-assessment and peer assessment.

${ }^{212}$ Boud, Cohen, and Sampson, "Peer learning and assessment."

213 Nicol and Macfarlane-Deck, "Formative assessment and self-regulated learning." 
judgments'; worry about favoritisms and friendship influencing marks; feel it is the responsibility of the lecturer and so on. ${ }^{214}$

Students in this method can share understandings of what is required with other students. ${ }^{215}$ Peer dialogue enhances the students' sense of selfcontrol over learning. ${ }^{216}$ It enhances a greater sense of accountability, responsibility and motivation. It increases the speed of feedback; helps students to develop skills and working together for long life learning such as giving feedback, self-evaluation, negotiation skills, and justifying point of view; ${ }^{217},{ }^{218}$ improves the quality of their work; develops the students' ability to work cooperatively. ${ }^{219}$ Peer learning can contribute to the social and psychological needs of learners. It can encourage students to engage in reflection and exploration of ideas; and it can help students to gain more practice in communications..$^{220}$

Self-assessment and peer assessment plays an important role in learning and teaching methods. The active students' participation in assessment is very important for their future working life. ${ }^{221}$ The skill of self and peerassessment is very important to develop the lifelong learning. ${ }^{222}$ The selfassessment, peer-assessment and group assessment encourage the deep learning approach. ${ }^{223}$

\section{II.7. Constructive Alignment}

Constructive alignment refers not to what the teacher is going to teach, but rather what the outcome of that teaching is intended to be which names the intended learning outcomes. ${ }^{224}$ It means creating links or co-ordinates between the course/program learning outcomes, teaching and learning

${ }^{214}$ Norton, “Assessing student learning," 141.

215 Ibid., 138.

${ }^{216}$ Nicol and Macfarlane-Deck, "Formative assessment and self-regulated learning."

217 Bloxham and Boyd, Developing Effective Assessment in Higher Education: a practical guide, 23 .

${ }^{218}$ Boud, Cohen, and Sampson, "Peer learning and assessment."

${ }^{219}$ Ndebele and Maphosa, "Exploring the Assessment Terrain in Higher Education," 154.

${ }^{220}$ Boud, Cohen, and Sampson, "Peer learning and assessment."

${ }^{221}$ Spiller, Assessment matters:Self-assessment and peer assessment.

${ }^{222}$ Sluijsmans, Dochy, and Moerkerke, the use of self-, peer-, and co-assessment in higher education.

${ }^{223}$ Brown, "Assessment for learning."

${ }^{224}$ Biggs and Tang, Teaching for Quality Learning at University. 
activities, and assessment methods to support students' learning. ${ }^{225}$ Constructive refers to how the students structure meaning through different learning activities, while alignment refers to how the teacher create connect between learning activities and assessment tasks to achieve the intended learning outcomes. ${ }^{226}$

The constructive alignment used in different countries for education quality assurance. The benefits of effective constructive alignment are more directed to the students than teachers. Because this method tells the students, not only what they are supposing to be learned, but how and at what standard. ${ }^{27}$ In constructive alignment we start with and define the intended learning outcome and align the assessment methods with those outcomes. It means starting with intended learning outcomes of the course and work backwards. ${ }^{228}$

Alignment is a course design methodology emphasizes on the intended learning outcomes. ${ }^{229}$ It refers to what extent the learning outcomes statements match with what we teach. ${ }^{230}$ It means what teacher does to set up learning environments that supports the appropriate learning activities to achieve the desired learning outcomes. This means that how the teaching methods and assessment tasks are aligned to learning activity assumed in intended learning outcomes. ${ }^{231},{ }^{232}$ Alignment the elements of learning, teaching and assessment are complement one another to form an integrated whole..$^{233}$

Curriculum/course alignment involves organizing of its aims, goals, content, learning outcomes, teaching and learning strategies, instructors' roles, students' roles, technological affordances, assessment, and evaluation in a coherent structure in order to improve both the coherence

${ }^{225}$ Gibbs, Kennedy, and Vickers, "Learning Outcomes, Degree Profiles, Tuning Project and Competences."

${ }^{226}$ Biggs and Tang, Teaching for Quality Learning at University.

227 Ibid.

${ }^{228}$ Nulty, Curriculum Design.

${ }^{229}$ Bloxham and Boyd, Developing Effective Assessment in Higher Education.

${ }^{230}$ Peggy L. Maki, Assessing for Learning: Building a Sustainable Commitment Across (2nd. Stylus Publishing and AAHE., 2004).

${ }^{231}$ Ndebele and Maphosa, "Exploring the Assessment Terrain in Higher Education."

${ }^{232}$ Goff et al., learning Outcomes Assessment: A Practitioner's Handbook.

${ }^{233}$ Lynn Clouder, "Promotion of reflective learning, teaching and assessment through curriculum design. Occasional Paper No. 10: Connecting Reflective Learning, Teaching and Assessment." In Connecting Reflective Learning, Teaching and Assessment, ed by Helen Bulpitt and Mary Deane (London: Higher Education Academy, Health Sciences and Practice Subject, 2012), 8-17. 
of curriculum and student learning and determine the success of any learning environment. ${ }^{234},{ }^{235}, 236$

\section{What is the T MEDA Project?}

The Tuning Middle East and North Africa project (T MEDA) funded and supported by the European Commission and organized by Tuning Academy/ University of Deusto, Spain. It is a project by and for universities. ${ }^{237} \mathrm{~T}$ MEDA project aims to implement the Bologna tools in Southern Neighboring Area universities through building of a framework of comparable, compatible and transparent programs of studies. ${ }^{238}$ The objectives of this project was to develop Tuning Reference Points in four subject areas (Law, Healthcare and Nursing, Architecture and Tourism) to develop, implement, monitor and improve degree programs and to promote regional and international cooperation between Southern Neighboring Area universities and European universities. ${ }^{239}$ The name Tuning was chosen to reflect the idea that the universities do not look for the uniformity or unified, but simply for point of reference convergence and common understanding. ${ }^{240}$

Tuning process aims to make education programs compatible and comparable. ${ }^{241}$ The tuning approach respects and promotes the diversity of the degree programs and aims to develop a common language between all stakeholders that involve within process. It aims also to develop the generic and specific competences and intended learning outcomes for different subject areas. Tuning methodologies focus on (re)designing, developing, implementing, evaluating, and enhancing the degree programs with contribution with different stakeholders and partners from Europe, Latin America, Asia, South Africa, etc. additionally, it aims to promote international corporation between universities to develop, implement, monitor, and improve different degree program. ${ }^{242}$

${ }^{234}$ Popenici and Millar, Writing Learning Outcomes: A Practical Guide for Academics.

${ }^{235}$ Thomas C. Reeves, "How do you know they are learning?: the importance of alignment in higher education." International Journal of Learning Technology 2, no. 4 (2006): 294-309.

${ }^{236}$ Clouder, "Promotion of reflective learning, teaching and assessment through curriculum design."

237 T-MEDA, T MEDA. 2013. http://tuningmeda.org/.

238 Ibid.

239 Ibid.

240 Tuning, Introduction to Tuning.

${ }^{241}$ Sanches and Ruiz, Competence-based Learning.

${ }^{242}$ T-MEDA, T MEDA. 2013, http://tuningmeda.org/. 
The competences approach changes the concepts from teacher-center approach to student-centered approach, which become a key issue in the Bologna process and the European Credit Transfer System. These processes aim to make programs more comparable, compatible, and transparent, which expressed in terms of competences and learning outcomes. ${ }^{243}$

This project held 5 general meetings. During these meetings and for each subject area, the generic and specific subject competences were discussed, agreed, and listed, The Meta profile were designed, different programs were designed and compared, and the universities that implemented of the $\mathrm{T}$ MEDA pilot program were chosen.

In addition, a staff development online course: 'Course design for outcomes based learning in higher education' for each universities that implemented the pilot program had taken by distance mode from May to August 2015. This online course covered the following topics: introduction to the value of reflective practice; competences in course design for higher education; writing learning outcomes; from competences to intended learning outcomes (ILOs): developing competences through sequenced steps; Teaching, learning, and assessment learning outcomes; Alignment of ILOs with teaching, learning and assessment activities; and summing up. The online course directors were Professor Arlene Gilpin and Maria Yarosh from university of Deusto, Spain.

Moreover, workshop was held at the Hashemite University, Jordan on May 17-22, 2015. It covered the following main topics: Introduction: What is Tuning and what does it offer to Higher Education?; how do we make high quality degree programs?; designing a degree program in practice; writing competences and learning outcomes; design of the degree program to be implemented; teaching, learning and assessment in student-centered degree programs.

Based on his participation on T MEDA meetings, online course, and workshop, the first author used the T MEDA competences and Meta profile to redesign and develop architectural degree program and its vision, mission and adjectives; define and develop the intended learning outcomes; and align the teaching and learning methods and activities with assessment tasks for all courses in architectural degree program at the Hashemite University. The first author presented his work many times to the architectural faculty members at $\mathrm{HU}$ and the booklet results distributed to them to get feedback. Finally, all the faculty members were sit together and discussed all his work in details, then they modified and agreed his work.

${ }^{243}$ Ibid. 
The next sections will answer question number three: what are the generic/specific competences and Meta-profile that are required to design the architectural program at the Hashemite University, Jordan?

\section{III.1. T MEDA generic and specific competences of architectural program of the Hashemite University, Jordan}

Competences mean the proven ability to use knowledge and skills in work, professional and personal practice. ${ }^{244}$ Generic competences are common competences that can be identified in different degree programs. ${ }^{245}$ Generic competences are multifunctional, multidimensional, transversal, instrumental, interpersonal, and systematic competences that pertaining to each profession. ${ }^{246}$ Specific competences are intimately related to specific knowledge of an area of study. ${ }^{247}$

III.1.1. Specific competences of architectural degree program of the Hashemite University, Jordan

1. Appreciation of the social and cultural role of Architecture

2. Ability to design buildings and/or urban development projects that blend with the surrounding environment and fully satisfy local human, social and cultural requirements at different levels and complexity

3. Skill in formulating creative and innovative ideas and transforming them into architectural creations and urban planning

4. Knowledge of history and theory of Architecture and related human sciences and engineering

5. Awareness of current architectural ideas and practices at local and global levels

6. Understanding of the ethical issues involved in architectural design and practice

${ }^{244}$ Crespo, et al., "Aligning Assessment with Learning Outcomes in Outcome-based

245 Tuning, Introduction to Tuning.

${ }^{246}$ Sanches and Ruiz, Competence-based Learning.

247 Tuning, Introduction to Tuning. 
7. Awareness that investigation and research are essential components of architectural creations

8. Awareness of the continuous changes of architectural ideas and practices

9. Ability to think, perceive and conceive spaces three dimensionally in different scales

10. Skill in reconciling all the factors involved in architectural design and urban development

11. Mastery of the media and tools used for communicating verbally, in writing and/or volumetrically architectural and urban development ideas and designs

12. Ability to evaluate, enhance and preserve architectural and urban local heritage and recognize the importance of its relation with current architectural developments

13. Ability to work within, or lead constructively interdisciplinary teams

14. Knowledge of aesthetics and arts, and understanding their role as key factors in the quality of architectural thinking and design

15. Capacity to design projects assuring environmental, social, cultural and economic sustainability

16. Ability to conceive and integrate structural, construction, environmental and installation systems to architectural designs

17. Ability to design buildings to accommodate individuals with varying physical abilities

18. Knowledge and ability to apply legal framework, safety regulations and technical codes controlling activities of the profession

19. Capacity to produce comprehensive construction documents

20. Capacity for planning, programming, budgeting and managing architectural projects

21. Awareness of methods of execution practiced in architectural projects

22. Ability to develop site plans and landscape designs

23. Understanding the importance of, and ability to incorporate new and renewable energy sources in building design 
24. Understanding of the basic principles and appropriate application of construction materials including local ones

25. Awareness of the importance of client's role in the design process

26. Ability to analyze and incorporate relevant precedents into architectural design projects

III.1.2. Generic competences of architectural degree program of the Hashemite University

1. Manage time effectively

2. Communicate orally and in writing with different audiences

3. Maintain continuous education

4. Have critical thinking, analysis and synthesis

5. Identify and resolve problems

6. Make logical decisions

7. Work in an interdisciplinary team

8. Lead effectively

9. Work autonomously

10. Maintain quality of work

11. Act ethically with social responsibility

12. Apply knowledge in practical situations

13. Communicate in a second language

14. Be innovative and creative

15. Be flexible and adapt to different situations.

16. Empower others

17. Search for information from a variety a sources

18. Commitment to the protection and preservation of the environment

19. Commitment to human rights

20. Commitment to health and safety procedures

21. Commitment to the preservation of cultural heritage and values

22. Having organizational skills

23. Having sense of dedication

24. Having respect for diversity and multiculturalism

25. Having skills in the use of information and communication technologies

26. Being initiative

27. Being self-motivated

28. Being assertive 


\section{III.2. Meta profile (degree Profile) of architectural degree program of the Hashemite University, Jordan}

The Meta profile specifies the subject areas and indicates the special aims and features that distinguish this program from the other similar programs. It is described in terms of the competences and learning outcomes ${ }^{248}$ and consists from the merging between generic and specific-subject competences. ${ }^{249}$

Architectural program focuses on design studios, courses in design and visualization, building construction and technological aspects, history and theory, urbanism and landscape, and professional practice and work ethics serve as a basis for developing a comprehensive approach to architectural design. Therefore, the Meta profile in architectural program consists from four main pillars: design ability, construction and technological ability, the theoretical background and socio cultural values, and professional practice and work ethics.

\section{III.2.1. Design Ability}

The area of design and visualization encompasses required studios, option studios, electives that concentrate on design logic and skills, and courses that support design thinking and representation. The design studio develops the students':

1. Ability to design building, sites, and/or urban development projects in a sustainable manner (socially, culturally, economically, environmentally)

2. Ability to think, perceive and conceive spaces three dimensionally and communicate verbally, in writing, graphically, and/or volumetrically

3. Skills in formulating creative and innovative ideas and transforming them into architectural creations and urban planning

4. Ability to design buildings to accommodate individuals with varying physical abilities

5. Ability to analyze and incorporate relevant precedents into architectural design projects

${ }^{248}$ CoRe, A Tuning Guide to Formulating Degree Program Profiles, 20.

249 Tuning, Introduction to Tuning. 


\section{III.2.2. Construction and technological ability}

Construction and technological aspects courses explore, as an integral part of the architectural design process, the physical context; the properties of natural forces; and building structural systems. These courses will develop the students':

1. Ability to conceive and integrate structural, construction, renewable energy systems, and environmental and installation systems to architectural design

2. Capacity to produce comprehensive construction documents

3. Awareness of methods of execution practiced in architectural projects

4. Understanding of the basic principles and appropriate application of construction materials including local ones

III.2.3. The theoretical background and socio cultural values

Courses in history (contemporary) and theory examine attitude concerning the design of building, landscape, and cities that may contribute to a design process responsive to its broadest social and cultural context. Courses in urbanism and landscape address the study of aesthetic, economic, political, and social issues that influence large-scale environments.

These courses will develop the students':

1. Appreciation of the social and cultural role of architecture

2. Knowledge of history and theory of architecture and related human sciences and engineering

3. Awareness of current architectural ideas and practices at the local and global levels,

4. Ability to conduct investigation and research in the process of architectural innovation

5. Critical thinking, analysis and synthesis,

6. Ability to evaluate, enhance, and preserve architectural and urban local heritage and recognize the importance of its relation with current architectural developments 
7. Knowledge of aesthetics and arts, and understanding their role as key factors in the quality of architectural thinking and design

III.2.4. Professional practice and work ethics

In the area of practice, courses are concerned with issues related to the professional context of architecture and its practice and, in particular, with the architect's responsibility for the built environment. Courses in working drawing, contracts and specifications, quantity surveying, professional practice, and training will develop the students':

1. To act ethically pertaining issues related to architectural design and practice

2. Knowledge and ability to apply legal framework, safety regulation and technical codes controlling activities of profession

3. Capacity for planning, programming, budgeting and managing architectural projects

4. Ability to maintain quality of work

5. Ability to protection and preservation of the environment

6. Respect for diversity and multiculturalism

7. Work effectively in a team

8. Work under pressure

9. Manage time effectively

10. Maintain continuous education.

\section{Teaching, Learning, and Assessment activities in Architectural Design Courses (Design 5 as a Case Study) at the Hashemite University Jordan.}

The main aim of this section was to answer of the forth and fifth research questions. The forth a research question was: How can we design the course? How can the teaching, learning, and assessment activities in architectural design courses (design 5 as a case study) be best structured, organized, and aligned based on T MEDA project in order to allow students to achieve and 
reach the intended learning outcomes?. The fifth research question was: How can we implement the self and peer assessment methods in architectural design education?

\section{IV.1. General Description of Architectural Design Courses}

The architectural students are learning by doing and designing project (Design problem based learning or project-based learning approach). The design course depends on the instructors' reflection practice or learning from experience. ${ }^{250}$ The design courses are the core courses in architectural engineering education. In each semester, the architectural students should take one design course starting from basic design1, basic design 2, design 1, $2,3,4,5,6$, design thesis, and finally graduation design project. Each student must pass on the prerequisite design course in order to register on the next one (example, each student must pass in design 4 to register in design 5 and so on).

The natures of each architectural design courses are practical ones (6 credit hours). Each student is requested to design architectural projects (functionally, aesthetically, environmentally, and structurally). The instructors select different building types and projects and distribute them among the design courses. The design instructors start from simple design projects in first years to complex projects in the fourth and fifth years. In each design, each student requested to apply his/her understanding of the theory and history courses, construction courses, environmentally and sustainable courses, and professional practical courses in his/her design.

\section{IV .2. The Architectural Course Design}

As design instructors, we should answer the following questions before design the course. Who are our students? What topics or content do we teach? What kind of skills and knowledge the students should learn? What are the intended learning outcomes for each design phase? What are the assessment criteria and methods for each design phase? How can we assess students' learning? What teaching methods do we use? How can we develop the learning and teaching strategies that enable students to achieve the

${ }^{250}$ Clouder, "Promotion of reflective learning, teaching and assessment through curriculum design." 
intended learning outcomes? What do we need to do to improve students' learning?

\section{IV.3. The Nature of Design 5 Course at the Architectural Department at the Hashemite University (Case Study)}

This course introduces students to the field and practice of architectural mixed-use and twin-high-rise buildings within the urban context throughout one full semester project. The objective is to provide a foundation for understanding the various dimensions, requirements, limitations, and regulation roles of architectural mixed and twin-high-rise building projects in Jordan. This course employs a professional approach where the students will formulate the brief and requirements of the project as a result of existing architectural and socio-economical analysis of the study area. The project's site will be realistic one located on flat area. The focus will be on programming, conceptual design, design development, final architectural design (aesthetic values as well as functionality and constructability). Additionally, the environmental considerations should be taken into students' consideration when they design project; for example, material selection, life cycle impacts, energy needs, orientation, local specific environmental concerns (if any).

The design process requires understanding and applying building details that include structural, building materials, mechanical, electrical, and sanitation systems as well as architectural details. The nature of this project is framed by theoretical and contextual understanding that focusing on architectural expressional spaces.

\section{IV.4. Design 5 Course Design Process}

The design 5 course design depends on the Backward Design Model, that means identifying what the instructors do want the students to know, to be able to do, and perhaps even to be as a result of each phase design. This means that starting with intended learning outcomes of the course and work backwards. ${ }^{251}$ The course coordinator (first author) plans, prepares, defines, and arranges the course objectives, description, ILOs, Learning activities, teaching techniques, and assessment methods and then all the above distribute

\footnotetext{
${ }^{251}$ Maki, Assessing for Learning: Building a Sustainable Commitment Across.
} 
into each design phase. The design instructors meet to explain, discuss, add, modify, and agree of the above course design contents and elements.

Course syllabus is then prepared and designed. It is a job specification that refers to the content and subject matter ${ }^{252}$ it includes the course description, ILOs, learning activities, teaching methods and techniques, appropriate assessment methods, and time table for each design phase in full details to give students big pictures in order to arrive to overall grades or marks. ${ }^{253}$ The students work load was discussed and information was given to the students. The students' workload is one of the main elements of the course design. It can be interpreted as the number of the working hours that are needed to follow classes. It consists of both from the class contact hours and of the individual time spent to do different learning activities. In design 5 , student workload is 32 hour per week.

At the end of each design phase, the course coordinator prepares the design requirements, ILOs, learning activities, teaching techniques, and timetable for the next design phase and explains them to the students. The architectural engineering students should know what expected to know, understand, how to present their work, and/or be able to demonstrate after completion of each design phase within definite time. The design requirements for each design phase should be clearly stated and understood by students. Additionally, the students should know how their work will be assessed and in which method and criteria.

For each design phase, the design instructors show the students three different examples from previous students' work: the first is almost completely meets their requirements. The second is in the moderate level of their expectations, and the final is failed to satisfy with their requirements. The design instructors also explain why each case has got this classification.

Before the final submission of each design phase, the instructors discuss with the students how to present and sell their design requirements and how to negotiate and discuss their design with the jury members (how to communicate their design graphically and verbally). With the final design submission, each student should submit a poster showing his/her design development in each design phase.

The instructors' role is to explain architectural concepts, principles, and design requirements. They present architectural information, develop the assessment criteria based on the ILOs and teaching and learning activities,

${ }^{252}$ Khwaja, Akhtar, and Mirza, Module III: Currculum Developmet, Assessment and Evaluation.

${ }^{253}$ Norton, “Assessing student learning,” 136. 
guide the students' design process to achieve the ILOS, and develop students' useful skills and design knowledge in order to get a good job. ${ }^{254}$

\section{IV.5. Deep Learning Approach}

Deep approach adapted to studying architectural design in order to encourage students to achieve high-quality learning outcomes. ${ }^{255}$ This deep approach focuses on understanding of the nature of design problem, analysis/ synthesis, conceptual design, design development, and final design. This process is incorporated into students' existing knowledge to develop and enhance their design skills and abilities. This approach is being associated with students' intrinsic motivation. ${ }^{256}$ The intention of the deep approach to learning in architectural design is to understand through an active engagement with the design knowledge. ${ }^{257}$

\section{IV.6. Intended Learning Outcomes (ILOs) of Design 5 Course}

Based on the course objectives and course design we developed the following intended learning outcomes (ILOs) based on the design process. By the end of this design 5 course, students should be able to:

\section{IV.6.1. Design Ability}

a1) Define the nature of project, requirements, factors, regulation roles, and issues that influence the design of architectural mixed use and high-rise mix use building in a complex urban context in world and Jordan.

a2) Breakdown the architectural mixed-use and high-rise buildings projects into manageable inter-relatable partial components; compare different design objectives, and sort them in terms of priorities in the design process.

${ }^{254}$ Sherria L. Hoskins and Stephen E. Newstead, "Encouraging Students motivation," in A Handbook for Teaching and Learning in Higher Education: Enhancing Academic Practice, ed. by Heather Fry, Steve Ketteridge and Stephanie Marshall, 27-39. (New York: Routledge, 2009).

255 Spiller, Assessment matters:Self-assessment and peer assessment.

${ }^{256}$ Hoskins and Newstead, "Encouraging Students motivation."

257 Norton, “Assessing student learning," 135. 
a3) Classify and explain the related topics to mixed-use and high-rise building design developments projects and then list the principles of design concerning large-scale projects.

a4) Select, review, describe, analyze, and critique similar design precedents by choosing and analyzing of 3 different case studies (local, regional, and international).

a5) Converse, question and analyze the topics of the mixed-use and high-rise building design project. For 3 case studies, analyze their sites and environmental context, analyze existing spatial concepts and schematic design; analyze the functional design, analyze the horizontal and vertical circulation, analyze the masses and the relationships between in and outside spaces, analyze threedimensional design with images, analyze the elevations and openings, and generate of architectural design programs,...

a6) Recognize and analyze the design site forces, context, spatial urban structure, building codes, environmental context (natural, manmade and human).

a7) Acquire experience by dealing with urban context: documentation, analyzing, and understanding its evolution.

a8) Adapt critical thinking design processes by using inductive, deductive and abductive (process of inference to the best explanation) reasoning; and using analysis synthesis design cycle to structure the design knowledge and create the conceptual design and models.

a9) Develop graphical thinking and communication skills in interpreting the design concept into spatial experience as it relates to urban design.

a10) Elaborate the conceptual intellectual design that addresses issues and opportunities at the urban scale, and critically synthesis urban site conditions toward the development of innovative spatial experience.

a11) Apply basic organizational, spatial, structural, environmental consideration, and constructional principles to the conception and development of interior and exterior spaces, building elements, and components to create 3 different conceptual spatial design and models.

a12) Combine all previous knowledge to improve the design. 
a13) Chose one design concept and develop it to more architectural details, design the structural system, solve different circulation systems (Vehicles, users circulation - indoor and outdoor), deal with internal designs, deal with Indoor/outdoor spatial compositions and relationships, chose the construction materials...

a14) Evolve the developed design into final architectural design projects by using an appropriate range of media (final plans, elevations, sections, models, 3D perspectives, design booklet).

a15) Sell and present the design orally and graphically by using appropriate representational media and design-based software, different communicational skills, architectural vocabulary and related terminology.

IV.6.2. Construction and Technological Ability

b1) Apply construction elements and building materials into architectural design process.

b2) Deal with structural issues.

b3) Apply building code requirements in design projects.

b4) Develop a sound knowledge and understanding of construction technology and environmental sustainability and an awareness of the related specialisms of structural and environmental engineering and their role in coherent integrated designs.

IV.6.3. Theoretical Background and Socio-Cultural Value

c1) Employ basic methods of data collection and analysis to inform all aspects of the programming and design process.

c2) Identify and list principles of design of architectural mixed-use and high-rise buildings projects in accordance with relevant technical disciplines.

c3) Define strategies for problem solving, conceptual development and poetic expression at all levels of the design process of a building complex. 
c4) Defines the urban spaces and their relations to buildings.

c5) Outline principles of preparation and presentation of complex design projects in a variety of contexts and scales.

c6) Identify different architectural functions and circulation patterns.

c7) Identify appropriate forms and structure systems for different architectural functions.

c8) Identify different site boundaries and all environmental contexts (natural, man-made and human).

c9) Identify the principles of climatic considerations, and energy consumption and efficiency in a certain design.

c10) Identify the processes of spatial change in the built and natural environments; patterns and problems of cities; and positive $\&$ negative impacts of urbanization.

c11) Apply professional expertise and skills to the benefit of society as a whole.

c12) Develop an understanding of the historical, theoretical and societal contexts of architecture and their role in providing the specific identity and significance of architecture as a design and research discipline.

\section{IV .6.4. Professional Practice and Work Ethics}

d1) Develop team work co-operative skills.

d2) Communicate effectively orally and graphically.

d3) Develop interpersonal skills and effective self-management.

d4) Effectively manage tasks and resources within constrained time.

d5) Employ appropriate architectural communication and representational media, including computer technology, to convey essential formal elements at each stage of the programming and design process.

d6) Work under pressure.

d7) Practices the neatness and aesthetics in design and approach. 
d8) Respect all alternative solutions; changes in original plan of the project, differences in style, culture, experience and treat others with respect.

d9) Contribute positively to the aesthetic, architecture and urban identity, and cultural life of the community.

\section{IV.7. Design Process}

Throughout the authors' practical and teaching experiences, the architectural design process is a cyclic process that applies the following phase:

a) Analysis design phase: Understanding the nature of project, analysis the site, analysis of 3 different similar case studies, and creating design program. This phase helps students to understand the project and site.

b) Synthesis stage and conceptual design phase: the main aim of this phase is to create different design concepts. This phase helps students to apply their critical thinking and helps them to be flexible and fluency of their thoughts. The flexible and fluency of thoughts are the major elements of creativity.

c) Evaluation Phase and initial development: each student required to evaluate and choose one design concept and develop it initially to architectural plans and mass models.

d) Development phase: the main aim of this phase is to develop the initial architectural plans and masses to more architectural, structural, mechanical details.

e) Final Design Phase: the main aim of this phase is to present the students' $2 \mathrm{~d}$ drawings, $3 \mathrm{~d}$ drawings, architectural and structural details, and models as final design product.

\section{IV.8. Assessment Methods}

Feedback is one of the most important aspects of supporting students' learning. ${ }^{258}$ It can be seen as a message to the students about what is right and wrong, good or bad, and strengths and weaknesses. Students use this information to make subsequent improvements. ${ }^{259}$

${ }^{258}$ Gosling,"Supporting student learning."

${ }^{259}$ Nicol and Macfarlane-Deck, "Formative assessment and self-regulated learning." 
In design studio, the students pay more attention to the feedback, understand it, and act on it for future improvements. ${ }^{260}$ Good feedback practice helps to clarify what good performance; offers high quality information to the students about their own design learning; supports the students' motivational believe and self-esteem; provide teacher with the necessary information about their methods and process of teaching. ${ }^{261}$

The purpose of assessment is to make judgments about how design meets appropriate quality. It frames how students learn and what they achieve. ${ }^{262}$ Validity of assessment refers to whether assessment measures what its intended to measure: knowledge, understanding, skills, contents, information, behavior, etc. To achieve the validity of assessment, the outcomes should be clearly stated and appropriate assessment method should be selected and used. It used to ensure that the students are marked fairly. ${ }^{263}$ Additionally, reliability is concerned with grading within the same provided criteria. ${ }^{264}$

Assessment methods should be clear from earliest stages of course. It should be transparency and explained in details to the students. It should be fully aligned with all other aspects of course design ${ }^{265}$ to give students feedback in order to develop their work. ${ }^{266}$ In design 5, the instructors follow different assessment methods for each design phase: self-assessment method, peer-review assessment method, instructors' assessment, internal and external jury assessment method.

The following sections will answer the fifth research question: How can we implement the self and peer assessment methods in architectural design? (The researchers' practical methods)

\section{IV .8.1. Self-Assessment Method of design 5 course}

In self-assessment method, the researchers prepare the assessment criteria for each design phase based on ILOs, design requirements, learning activities, and teaching techniques. Intensive conversation and negotiation with students about the design phase requirements and the intended learning

\footnotetext{
${ }^{260}$ Bloxham and Boyd, Developing Effective Assessment in Higher Education, 21.

${ }^{261}$ Nicol and Macfarlane-Deck, "Formative assessment and self-regulated learning."

${ }^{262}$ Boud, Assessment 2020: Seven propositions for assessment reform in higher education.

${ }^{263}$ Ndebele and Maphosa, "Exploring the Assessment Terrain in Higher Education,"152.

264 Ibid.

265 Boud, Assessment 2020: Seven propositions for assessment reform in higher education.

266 Craddocka and Mathiasb, "Assessment options in higher education," 136.
} 
outcomes of each phase is needed before any practice of self-assessment. ${ }^{267}$ The students must know these criteria before the design phase start to meet the instructors' expectations.

On the self-assessment method, each student should evaluate and assess his/her work based on the assessment criteria. Additionally, the instructors show the strengthen and weakness in each student's work; define what are the missing and mistakes in each work; make suggestion to improve each work; and review the assessment criteria with each student as a checklist.

The self-assessment helps the students to make judgment about their design progress, motivate them for further learning, encourage them to focus on the process of learning, accommodate diversity of learning experience and background, enhance the quality of learning, and prepare student to solve problem in creative ways. ${ }^{268}$

\section{IV.8.2. Small Group Teaching Methods and Peer-Assessment of design 5 course}

Small group teaching method is a form of peer, collaborative or cooperative learning to help students to meet the variety of intended learning outcomes. ${ }^{269}$ It refers to assessment of students by other students within a group. This method encourages peer learning and peer support; enhance the collaborative learning; encourage students to learn from themselves; provide opportunities for students to clarify and refine their understanding of the concepts through discussion and rehearsal with peers; ${ }^{270}$ and equip students with the self-confidence and facilitate group cohesion. ${ }^{271}$ It requires deep understanding of course content ${ }^{272}$ There is strong evidence from architectural design students that they enjoy and benefit a lot from this method. ${ }^{273}$

In design 5 design studio, small group teaching method used (group discussion) to teach student how to think, engage, and share their own and other design learning. This method requires wide knowledge and details of

\footnotetext{
${ }^{267}$ Spiller, Assessment matters:Self-assessment and peer assessment.

268 Ibid.

${ }^{269}$ Boud, Cohen, and Sampson, "Peer learning and assessment."

${ }^{270}$ Ndebele and Maphosa, "Exploring the Assessment Terrain in Higher Education."

271 Sandra Griffiths, "Teaching and learning in small groups," in A Handbook for
} Teaching and Learning in Higher Education: Enhancing Academic Practice, ed. by Heather Fry, Steve Ketteridge and Stephanie Marshall, 72-84. (New York: Routledge, 2009).

${ }^{272}$ Boud, Cohen, and Sampson, "Peer learning and assessment."

273 Griffiths, "Teaching and learning in small groups." 
design subject. The group teaching method is a critical mechanism to develop key skills, improve self-confidence, develop the teamwork and interpersonal communication, and develop their design ideas. ${ }^{274}$

Throughout different design phases, the design instructors encourage students to share and discuss their design ideas and its developments with the other students and get feedback from them. The instructors divide students into groups of 5-8 students. In each class, new groups reformulate with completely new members. Each student in-group presents his/her design work in front of group members and he/she gets critique and feedback from each group member. Later on, the instructors join the group and discuss and critique each student's work in front of all group and ask each group member to critique the design concentrate on the strengthen and weakness design issues. In Peer-review assessment method, each group member requires assessing the other students' design work based on the same assessment criteria that provided by instructors. The authors know from their own experience and from other researchers that the students learn from the discussion among themselves more than learning from their instructors.

Peer discussions offer students with different alternative and strategies to solve the design problems and construct new meanings through negotiations. ${ }^{275}$ It can encourage collaborative learning; exchange the knowledge between students; develop the students' skills; get a wider range of design ideas about their work to promote development and improvement; encourage student to clarify, review, modify their design work, help them on how to sell their design ideas through scientific negotiations, and gain confidence and become more competent. ${ }^{276}$ Peer mentoring schemes can operate well if students are motivated to support or help other student. It can create an ethos between students themselves and encourage participation and interaction among themselves. ${ }^{277}$

IV .8.3. Jury Assessment of design 5 course

In jury assessment, the instructors invite some professors from the same department as internal jury and some professors from different Jordanian universities/architectural department as external jury. Additionally, the

\footnotetext{
${ }^{274}$ Ibid.

275 Nicol and Macfarlane-Deck, "Formative assessment and self-regulated learning."

276 Spiller, Assessment matters:Self-assessment and peer assessment.

277 Gosling, "Supporting student learning."
} 
instructors invite architects from architectural practical field who have architectural offices in different Jordanian cities. Each jury committee consists from 4 jury members: 2 from educational field and 2 from practical field. The aims of the design jury are to discuss critique, modify, suggest change, and then assess each student's work. Each jury member requires assessing each student's work based on the same assessment criteria that provided from instructors. The average of grades of the four-jury member and instructors' assessment will be the final grade for each design phase. This assessment method aims to eliminate the subjectivity and increase the objectivity of design assessment.

\section{IV.9. Constructive Alignment for Design 5 Course}

The instructors use the constructive alignment methods to align the main four elements of the course: course content; intended leaning outcome; teaching and learning activities; and assessments methods. The main aims to use constructive alignment are to explain the purpose of everything that the instructors do or ask students to do and to make the course structure clear to the students (for more details see table 1).

\section{IV.10. Evaluation of the Course Design Process, Teaching, Learning and Assessment Activities}

What do we want to do to improve students' learning?. Course evaluating is a way to understand the effect of our teaching on students' learning. ${ }^{278}$ The purpose of evaluation is to monitor of our teaching performance methods to pinpoint our achievements; to find if the instructors are doing ok; to define the strengths and weakness in their teaching methods; and to compare our teaching methods with other colleagues' methods. ${ }^{279}$ The course evaluation encompass the course structure and design; teaching learning strategies; assessment methods and tasks; academic regulations; and interrelationships between them. ${ }^{280}$

278 Dai Hounsell, "Evaluating courses and teaching," in A Handbook for Teaching and Learning in Higher Education: Enhancing Academic Practice, ed. by Heather Fry, Steve Ketteridge and Stephanie Marshall (New York: Routledge, 2009), 189-212.

279 Hounsell, "Evaluating courses and teaching," 198-199.

280 Ibid., 200. 


\begin{tabular}{|c|c|c|c|}
\hline \multirow{6}{*}{ 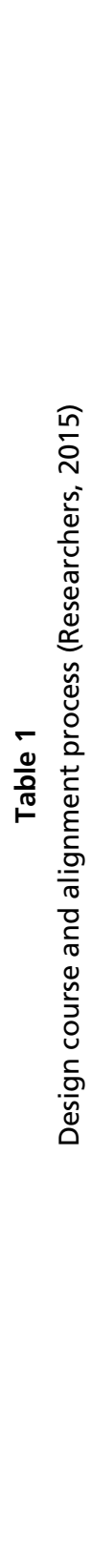 } & 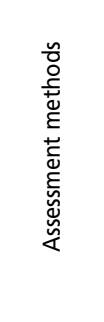 & 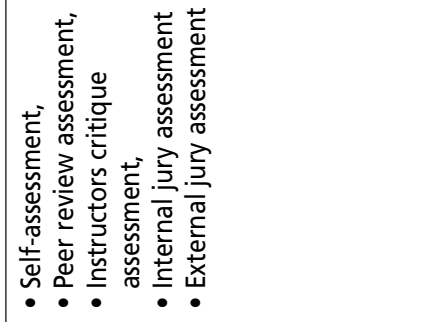 & 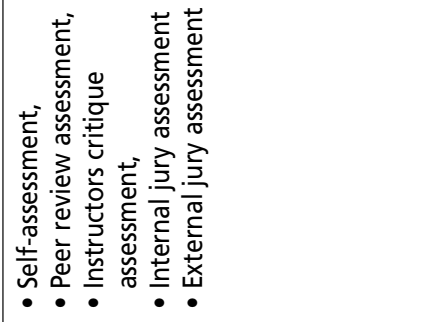 \\
\hline & 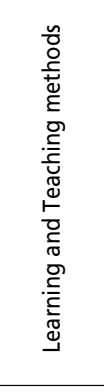 & 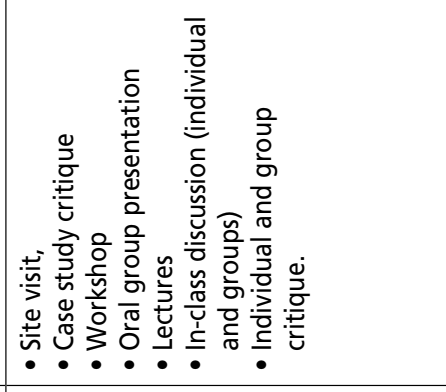 & 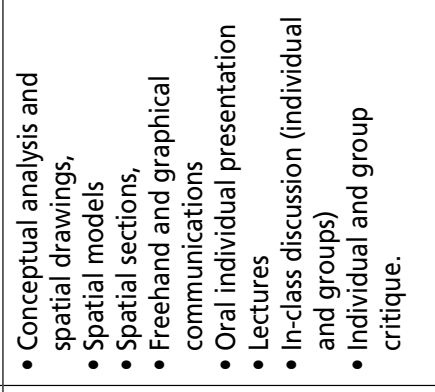 \\
\hline & 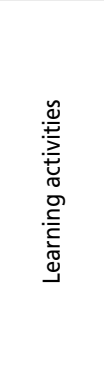 & 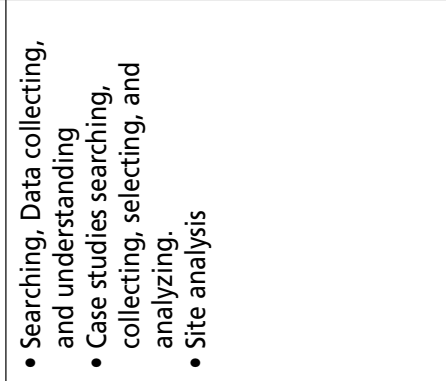 & 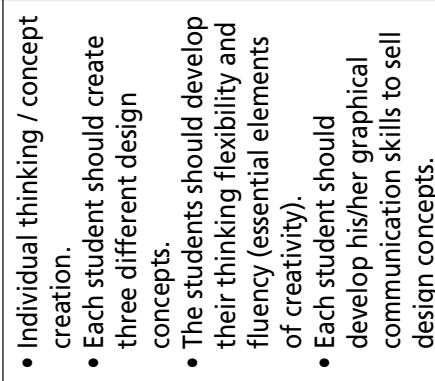 \\
\hline & $\stackrel{\text { ک }}{=}$ & 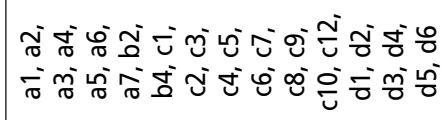 & 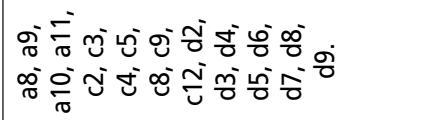 \\
\hline & 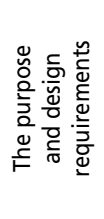 & 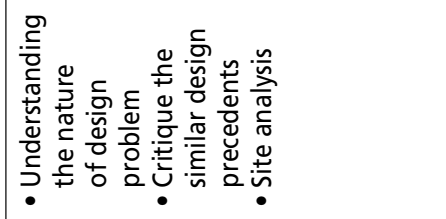 & 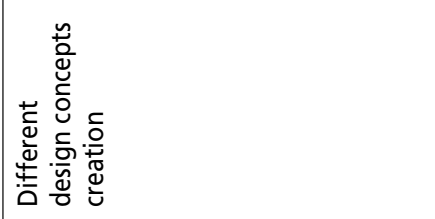 \\
\hline & 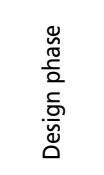 & 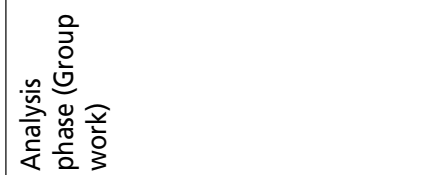 & 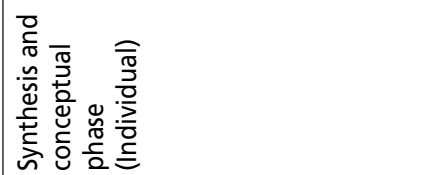 \\
\hline
\end{tabular}

Tuning Journal for Higher Education 


\begin{tabular}{|c|c|c|c|}
\hline 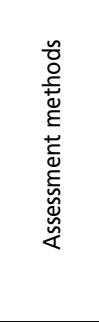 & 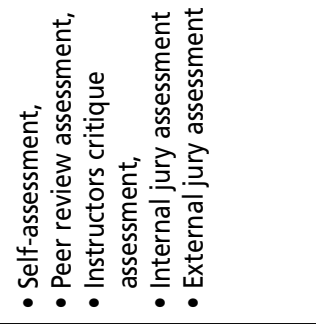 & 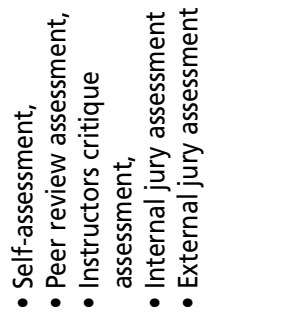 & 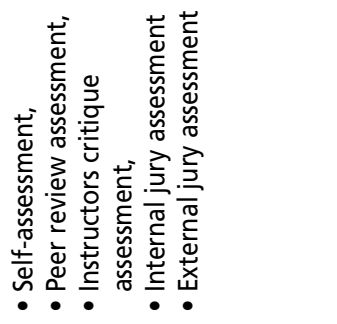 \\
\hline 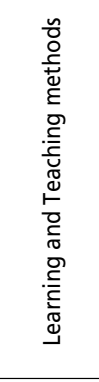 & 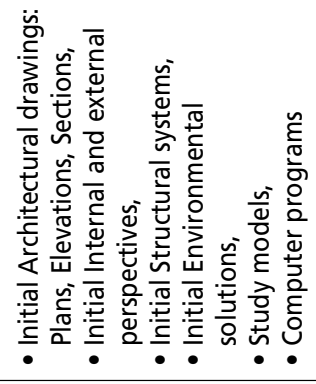 & 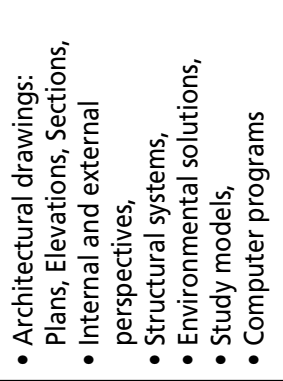 & 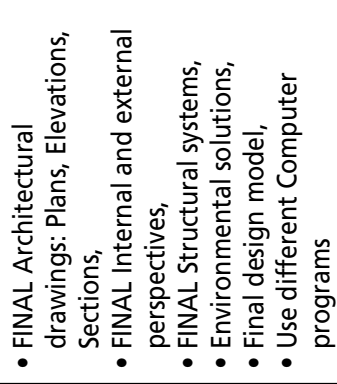 \\
\hline 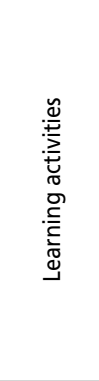 & 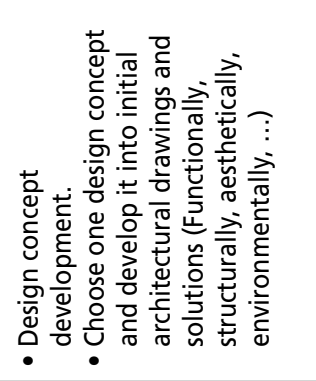 & 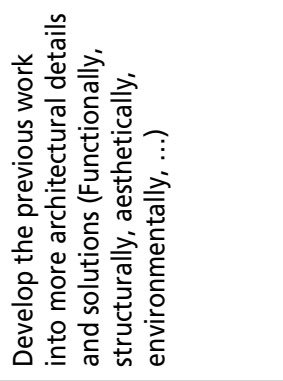 & 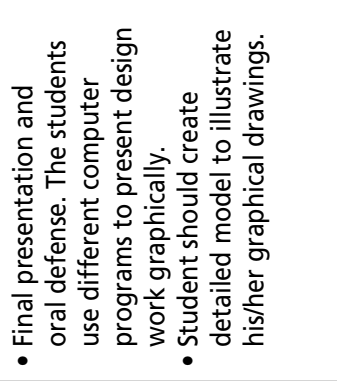 \\
\hline$\stackrel{\text { ㅇ }}{=}$ & 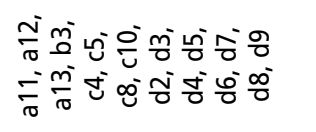 & 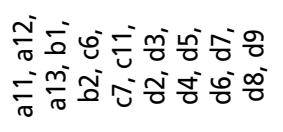 & 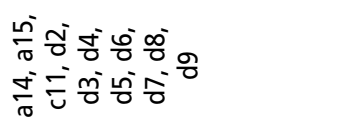 \\
\hline 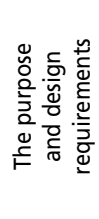 & 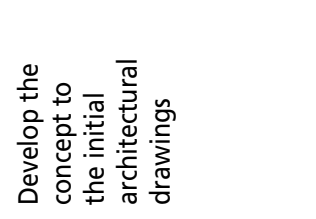 & 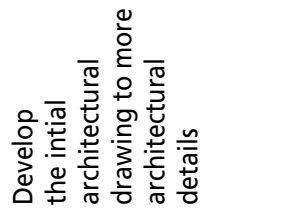 & 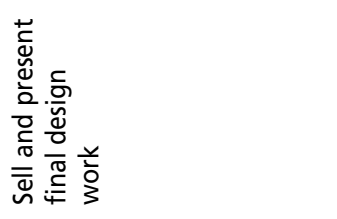 \\
\hline 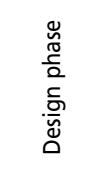 & 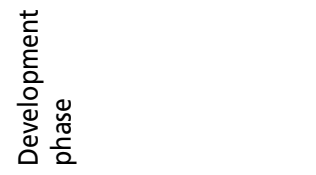 & 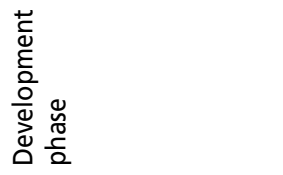 & 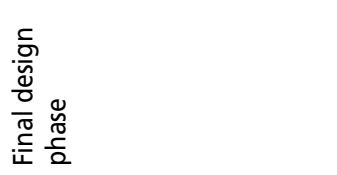 \\
\hline
\end{tabular}


The design 5 instructors developed the learning and teaching activities, methods and techniques over the past 4 years. After the assessment of each phase finished, the design instructors sit together and discuss, evaluate, and compare the results and students' ILOs achievements of each design phase with the same phase of previous years. Additionally, by the end of semester we ask students to fill the evaluation sheet about the course and ask them to give suggestion how to develop our learning activities, teaching techniques, and assessments methods for next year.

Moreover, different collected feedback used to evaluate the course: feedback from students and response the issue they raise; feedback from teaching colleagues and professional peers; and self-generated feedback. ${ }^{281}$ Questionnaire to the students; focus group and informal discussion with students for each design stage; face book group; instructors' notes; sitting and discussion session between instructors; internal and external jury feedback (direct observation); course evaluation from university were used continuous development and improvement of the design 5 learning and teaching approaches.

\section{IV.11. Results}

This good practice research, in the domain of competences-base studentcentereded approach in architectural design, used the T MEDA competences and Meta Profile to design the design 5 course. The course design depends on the Backward Design Model, ${ }^{282}{ }^{283}$ which means starting with intended learning outcomes and working backwards to define the course descriptions and objectives, learning activities, teaching methods and techniques, and assessment methods. The ILOs were distributed over the design phases; the design requirements of each design phase were agreed and defined; the learning activities, teaching methods, and assessment methods were determined; and finally the course syllabus was designed and aligned between all the above elements. After the course design was implemented, different feedback was collected to evaluate, develop, and improve the course design. Table 1 shows the course design and alignment process.

\section{Ibid., 201.}

282 Jack C. Richards, "Curriculum Approaches in Language Teaching: Forward, Central, and Backward Design.” RELC Journal 44, no. 1 (2013): 5-33.

${ }^{283}$ Bruce E. Fox and John J. Doherty, "Design to Learn, Learn to Design: Using backward design for information literacy instruction." Communications in Information Literacy 5, no. 2 (2012): 144-155. 


\section{IV.12. HU Students Perspectives on the Competencies-based Learning Approach}

The students were very satisfied with the competences-based learning approach. Reham stated, "the new approach leads to new and different experience of the design learning approach. It enables me to develop and structure my own design knowledge and learning in order to meet the intended learning outcomes and instructors' expectations". Anas stated, "This approach gives me a great sense of responsibility for my design learning and forces me to develop my master design skills in order to move to more professional design skills".

Bayan stated, "This is a great method to prepare me for future professional role. It raises the competition among students. It is clear and valuable method but it needs more working hours". Rawabi stated, "This method supports the interactive participation and negotiations on design studio. It enables me to understand the intended learning outcomes and engages on the assessment criteria". Amal stated, "This method encourages my personal design learning opportunities. It allows me to measure and evaluate my design progress and achievements".

Raneem stated, "This method improves my design knowledge because I know what I should to do from the beginning. This approach opens my mind to new design strategies". Hamza stated, "this method develops the ways of analysis, synthesis, thinking, creation, and evaluation and it enhances the sense that I am a real architect".

\section{Conclusion}

Recently, higher educational systems become increasingly oriented towards the competences-based student-centered learning and outcome approach. ${ }^{284}$, ${ }^{285}$ There are many faculties in Europe and US adopt the new learning philosophy, by contrast, Asia-Pacific reports many difficulties in implementing this effective reform. ${ }^{286}$ Therefore, the purpose of this research was to review, analyze, and synthesis the different related pieces from the higher education literature to explore, describe, and understand the holistic

${ }^{284}$ CoRe, A Tuning Guide to Formulating Degree Program Profiles, 25.

${ }^{285}$ Gibbs, Kennedy, and Vickers, "Learning Outcomes, Degree Profiles, Tuning Project and Competences."

286 Tremblay, Lalancette, and Roseveare, Assessment of Higher Education Learning Outcomes, 37. 
view of teaching and learning, program/curriculum design, generic and specific competences, intended learning outcomes, assessment and constructive alignment.

The present study was conducted in an attempt to answer the main research question: how can the architectural design courses be designed based on the required competences and how can the teaching, learning activities and assessment methods be structured and aligned in order to allow students to achieve and reach the intended learning outcomes?. This research used a case study driven best practice research method to answer the research questions based on the T MEDA pilot architectural program that implemented at the Hashemite University, Jordan.

Successful learning and teaching depends on the effectiveness of design courses/program in terms of specific and generic competences, program Meta profile, intended learning outcomes, learning and teaching activities, and assessment methods. ${ }^{287}$ All terms are interdependent to form the system of the course and send the same message. ${ }^{288}$ Designing the curriculum focuses on defining the conclusion before construction the plot. This means that when the instructor designs the course, he/she should start with defining the required outcomes that are to be achieved and then determine what must be taught. ${ }^{289}$ Teaching, learning, and assessment are to be a core activity to share, apply, test, and create knowledge. ${ }^{290}$ Teaching and learning should be enhanced by well planned and implemented formative assessment strategies properly aligned to intend learning outcomes and learning activities. ${ }^{291}$

This research found that it is important for architectural education to adapt the students-center learning method: the focus of efforts shifted from the design instructor to the students. The architectural department at the Hashemite University are willing to implement this effective reform of its teaching methods without that more difficulties. Additionally this research found that using the competences-based student-centered approach and constructive alignment in architectural design courses increases the effectiveness of teaching and learning methods enhances the design studio environment, and focuses on students' engagement in their design process.

287 Nulty, Curriculum Design.

288 Ibid.

289 Connie Vitale, "Foundations of university learning and teaching: A reflection on the curriculum alignment." e-Journal of Business Education \& Scholarship of Teaching 4, no. 2 (2010): 52-64.

290 GMIT, Code of Academic Policy No. 4.

291 Ndebele, and Maphosa, "Exploring the Assessment Terrain in Higher Education." 
Moreover, this research found that using different assessment methods in architectural design courses helps students to develop their learning outcomes; and informs teachers about the effectiveness of their teaching. The instructors and professors are required to develop and use different assessment methods and link them with the intended learning outcomes to give students feedback in order to develop their work. ${ }^{292}$ Additionally, the students should know the purpose of assessment, the intended learning outcomes of each design phase, the degree of quality and performance of their design, and the criteria of the judgment and evaluation before the assessment take place.

Furthermore, the involvement of students in assessment produces effective learning and enhances their design motivation. Self and peer assessment plays important role in learning and teaching methods. They encourage students to become independent learners; increase their selfesteem and develop the negotiation skills, and help them to engage actively in learning process. Therefore, different design assessment methods are the affective way to measure fairly the students learning outcomes. These methods increase the objectivity and decrease the subjectivity of design assessment.

Assessment of architectural design students' work is a significant component of effective teaching and learning. ${ }^{293}$ The purposes of design assessments are to guide and help students to develop their design learning outcomes; inform the students about their progress and estimate their performance; and inform instructors about the effectiveness of their teaching. (Cabrera, Colbeck and Terernzini 2001) found that learning outcomes positively associated with instructor interaction and feedback, collaborative learning, and clarity and organization. ${ }^{294}$

However, applying competences-based student-centered learning and outcome approach needs more time and staff to apply. Another problem is that some instructors resist changing to the new methods or approaches because they prefer to use their old and traditional systems. This paradigm shift requires a change of the traditional academic staffs` mind set. ${ }^{295}$

The application for this method at the first time needs intensive recourses, more time, and good cooperation between different instructors and subject coordinators. However, within the time this method will be more useful and

${ }^{292}$ Craddocka and Mathiasb, "Assessment options in higher education."

${ }^{293}$ Ndebele and Maphosa, "Exploring the Assessment Terrain in Higher Education."

${ }^{294}$ Alberto F. Cabrera, Carol L. Colbeck, and Patrick T. Terernzini, "Developing performance indicators for assessing classroom teaching practices and student learning: The case of engineering." Research in Higher Education 42, no. 3 (2001): 327-352.

${ }^{295}$ CoRe, A Tuning Guide to Formulating Degree Program Profiles, 19. 
interesting for the teacher and more effective and formative for the students. Finally, the development of architectural academic staff is needed to increase awareness of learning needs of all architectural students. They require redesigning and aligning their curriculum and courses syllabus according to the requirements of new methods.

\section{Bibliography}

AAAS. Designs for Science Literacy. New York: American Association for the Advancement of Science: Oxford University Press, Inc., 2000.

Ambrose, Susan A., Michael W. Bridges, Michele DiPietro, Marsha C. Lovett, Marie K. Norman, and RICHARD E. MAYER. How Learning Works: Seven Research-Based Principles for Smart Teaching. San Francisco: John Wiley \& Sons, Inc., 2010.

Arnau-Sabatés, L., M.T Marzo, M. Jariot, and J. Sala-Roca. "Learning basic employability competence: a challenge for the active labour insertion of adolescents in residential care in their transition to adulthood." European Journal of Social Work 17, no. 2 (2013): 252-265.

ASCC. ASCC alignment and assessment of students learning outcomes (SLOs): Training manual. California, California: Accrediting Commission for Community Junior College, 2008.

B\&FC. Learning, teaching, and assessment strategies guide. Blackpool and The Fylde College, 2013.

Baxter, Pamela, and Susan Jack. "Qualitative Case Study Methodology: Study Design and Implementation for Novice Researchers." The Qualitative Report 13, no. 4 (2008): 544-559.

BC. Every learning matters: Balton College higher education: Learning. teaching and assessment strategy 2013-2016. Bolton College, Bolton College, 2013.

Biggs, John B. "Aligning teaching for constructing learning." FOCUS 16, no. 1 (2008): $1-3$

Biggs, John. "Constructive alignment in university teaching." HERDSA Review of Higher Education, no. 1 (2014): 5-22.

Biggs, John, and Catherine Tang. Teaching for Quality Learning at University. 3rd. Maidenhead: Open University Press/McGraw Hill, 2007.

Bloxham, Sue, and Pete Boyd. Developing Effective Assessment in Higher Education: a practical guide. England: McGraw-Hill House, 2007.

Bodega, Irma Dolores Núñez y. "From curriculum to syllabus design: The different stages to design a program." MEMORIAS DEL III FORO NACIONAL DE ESTUDIOS EN LENGUAS 13, no. 3 (2007): 275-290.

Boud, David. Assessment 2020: Seven propositions for assessment reform in higher education. Sydney: Sydney: Australian Learning and Teaching, 2010.

Boud, David, Ruth Cohen, and Jane Sampson. "Peer learning and assessment." Assessment and Evaluation in Higher Education 24, no. 4 (2000): 413-426. 
Brown, Sally. "Assessment for learning." Learning and Teaching in Higher Education, no. 1 (2004): 81-89.

Cabrera, Alberto F., Carol L. Colbeck, and Patrick T. Terernzini. "Developing performance indicators for assessing classroom teaching practices and student learning: The case of engineering." Research in Higher Education 42, no. 3 (2001): 327-352.

CERI. Assessment for learning - the case fgor formative assessment. OECD/CERI International Conference, 2008.

Clouder, Lynn. "Promotion of reflective learning, teaching and assessment through curriculum design. Occasional Paper No. 10: Connecting Reflective Learning, Teaching and Assessment." In Connecting Reflective Learning, Teaching and Assessment, edited by Helen Bulpitt and Mary Deane, 8-17. London: Higher Education Academy, Health Sciences and Practice Subject, 2012.

CoRe. A Tuning Guide to Formulating Degree Program Profiles: Including Program Competences and Program Learning Outcomes. Bilbao: University of Deusto, Nuffic / TUNING Association, 2010.

Craddocka, Deborah, and Haydn Mathiasb. "Assessment options in higher education." Assessment \& Evaluation in Higher Education (Taylor \& Francis) 34, no. 2 (2009): 127-140.

Crespo, R. M., Najjar, J., Derntl, M., Leony, D., Neumann, S., Oberhuemer, P., Totschnig, M., Simon, B., Gutierrez, I., \& Delgado Kloos, C. "Aligning Assessment with Learning Outcomes in Outcome-based Education." EEE Education Engineering (IEEE EDUCON Education Engineering), 2010: 1-8.

Crowe, Sarah, Kathrin Cresswell, Ann Robertson, Guro Huby, Anthony Avery, and Aziz Sheikh. "The case study approach.” BMC Medical Research Methodology 100, no. 11 (2011): 1-10.

Fox, Bruce E., and John J. Doherty. "Design to Learn, Learn to Design: Using backward design for information literacy instruction." Communications in Information Literacy 5, no. 2 (2012): 144-155.

Fry, Heather, Steve Ketteridge, and Stephanie Marshall. "Understanding student learning." In A Handbook for Teaching and Learning in Higher Education: Enhancing Academic Practice, edited by Heather Fry, Steve Ketteridge and Stephanie Marshall, 8-26. New York: Routledge, 2009.

Gibbs, Andy, Declan Kennedy, and Anthony Vickers. "Learning Outcomes, Degree Profiles, Tuning Project and Competences." Journal of the European Higher Education Area, 2012: 72-88.

GMIT. Code of Academic Policy No. 4: Learning, Teaching \& Assessment Strategy 2010 - 2015. Galway-Mayo Institute of Technology, Dublin: Academic Council of GMIT, 2010.

Goff, Lori, et al. Learning Outcomes Assessment: A Practitioner's Handbook. Ontario: Higher Education Quality Council of Ontario (HEQCO), 2014.

Gosling, David. "Supporting student learning." In A Handbook for Teaching and Learning in Higher Education: Enhancing Academic Practice, edited by 
Heather Fry, Steve Ketteridge and Stephanie Marshall, 113-131. New York: Routledge, 2009.

Griffiths, Sandra. "Teaching and learning in small groups." In A Handbook for Teaching and Learning in Higher Education: Enhancing Academic Practice, edited by Heather Fry, Steve Ketteridge and Stephanie Marshall, 72-84. New York: Routledge, 2009.

Hall, Richard. "Aligning learning, teaching and assessment using the web: An evaluation of pedagogic approaches." British Journal of Educational Technology (Blackwell Publishers Ltd) 33, no. 2 (2002): 149-158.

Hoskins, Sherria L., and Stephen E. Newstead. "Encouraging Students motivation." In A Handbook for Teaching and Learning in Higher Education: Enhancing Academic Practice, edited by Heather Fry, Steve Ketteridge and Stephanie Marshall, 27-39. New York: Routledge, 2009.

Hounsell, Dai. "Evaluating courses and teaching." In A Handbook for Teaching and Learning in Higher Education: Enhancing Academic Practice, edited by Heather Fry, Steve Ketteridge and Stephanie Marshall, 198-212. New York: Routledge, 2009.

Kessels, Joseph, and Tjeerd Plomp. "A relational approach to curriculum design." Verschenen in Journal of Curriculum Studies 31, no. 6 (1999): 679-709.

Khwaja, Iftikhar Uddin, Shahnaz Akhtar, and Abida Mirza. Module III: Currculum Developmet, Assessment and Evaluation: Professional Competency Enhancement Program for Teachers (PCEPT). Islamabad: National Academy of Higher Education (NAHE): Learning Innovation Division and Higher Education Commission (HEC), 2014.

Knaack, Liesel. Enhancing your programs and cources through alighed learning outcomes. Vancouver Island University, Vancouve: Centre for Innovation and Excellence in Learning, 2015.

Knight, Peter T. "Summative assessment in higher education: practices in disarray." Studies in Higher Education 27, no. 3 (2002): 275-286.

LAM, Steve Y. W. "Outcome-Based Approach to Teaching, Learning and Assessment in Geomatics Higher Education: the Hong Kong Experience." Good Educational Practices, 2009: 1-10.

Maki, Peggy L. Assessing for Learning: Building a Sustainable Commitment Across. 2nd. Stylus Publishing and AAHE., 2004.

McCarthy, Marian. "Aligning Learning Outcomes, Learning Activities and Assessment.” Seminario Internacional SCT, . Pucón: Marian McCarthy, Augest $31,2011$.

Ndebele, Clever, and Cosmas Maphosa. "Exploring the Assessment Terrain in Higher Education: Possibilities and Threats: A Concept Paper." Journal of Social Science 35, no. 2 (2013): 149-158.

Nicol, David J., and Debra Macfarlane-Deck. "Formative assessment and selfregulated learning: Amodel and seven principles of good feedback practice." Studies in Higher Education 31, no. 2 (2006): 199-218. 
Norton, Lin. "Assessing student learning." In A Handbook for Teaching and Learning in Higher Education: Enhancing Academic Practice, edited by Heather Fry, Steve Ketteridge and Stephanie Marshall, 132-149. New York: Routledge, 2009.

Nulty, Duncan D. Curriculum Design. Griffith Institute, Griffith Institute for Higher Education, 2012.

Petrina, Stephen. Curriculum and Instruction Design: Advanced Teaching Methods for the Technology Classroom. University of British Columbia, Canada, 2007.

Pontuso, James F., and Saranna R. Thornton. "Is Outcomes Assessment Hurting Higher education?" The NEA Higher Education Journal Fall (2008): 61-70.

Popenici, Stefan, and Victoria Millar. Writing Learning Outcomes: A Practical Guide for Academics. The University of Melbourne, 2015.

Reeves, Thomas C. "How do you know they are learning?: the importance of alignment in higher education." International Journal of Learning Technology 2, no. 4 (2006): 294-309.

Richards, Jack C. "Curriculum Approaches in Language Teaching: Forward, Central, and Backward Design.” RELC Journal 44, no. 1 (2013): 5-33.

Rust, Chris. "The Impact of Assessment on Student Learning: How Can the Research Literature Practically Help to Inform the Development of Departmental Assessment Strategies and Learner-Centred Assessment Practices?" Active Learning in Higher Education (SAGE Publications) 145, no. 3 (2002): 145-158.

Sanches, Aurelio Villa, and Manual Poblete Ruiz. Competence-based Learning: A Proposal for the Assessment of Generic Competences. Bilbao: University of Deusto, 2008.

SAQA. The National Qualifications Framework: Curriculum Development. A publication of the South African Qualifications Authority, 2000.

Sluijsmans, D., F. Dochy, and G. Moerkerke. The use of self-, peer-, and coassessment in higher education: A review of literature. Open University of Netherlands, Otec, 1998.

Spiller, Dorothy. Assessment matters: Self-assessment and peer assessment. The University of Waikato, Hamilton, New Zealand: Teaching Development Unit/ Wāhanga Whakapakari Ako, 2012.

Stefani, Lorraine. "Planning teaching and learning: Curriculum design and development." In A Handbook for Teaching and Learning in Higher Education: Enhancing Academic Practice, edited by Heather Fry, Steve Ketteridge and Stephanie Marshall, 40-57. New York: Routledge, 2009.

Struyven, Katrien, Filip Dochy, and Steven Janssens. "Students' perceptions about assessment in higher education: A review." Assessment \& Evaluation in Higher Education 30, no. 4 (2005): 331-347.

T-MEDA. T MEDA. 2013. http://tuningmeda.org/.

Tremblay, Karine, Diane Lalancette, and Deborah Roseveare. Assessment of Higher Education Learning Outcomes: AHELO Feasibility Study Report - Volume 1 Design and Implementation. Organisation for Economic Co-Operation and Development (OECD), 2012. 
Tuning. Introduction to Tuning. Bilbao: Tuning Academy, 2007.

UNISA. Curriculum Policy. University of South Africa (UNISA), 2010.

UTAS. Guideline for good assessment practices. University of Tasmania, University of Tasmania Assessment, 2011.

UU. Assessment Handbook. Ulster University, 2015.

Vitale, Connie. "Foundations of university learning and teaching: A reflection on the curriculum alignment." e-Journal of Business Education \& Scholarship of Teaching 4, no. 2 (2010): 52-64.

Yin, Robert K. Case Study Research: Design and Methods. Vol. 5. SAGE Publications, 2014.

Zucker, Donna M. How to Do Case Study Research. College of Nursing, University of Massachusetts, Amherst: School of Nursing Faculty Publication Series, 2009.

\section{About the Authors}

AHMAD AL HUSBAN (alhusban2001@yahoo.com) is an architect. He is currently an assistant professor at the department of Architectural Engineering, at the Hashemite University (Jordan). He holds a Doctor of Architectural Design Degree (D Des, PhD) from the Interdisciplinary design institute at Washington State University in USA at 2012 with GPA (3.95). He holds a master degree in architectural engineering for Jordan University of Science and Technology (JUST), Irbid, Jordan (2007), and a Bachelor degree in architectural engineering also from JUST (1994). His research interest revolves around issues related to architectural design education, design thinking, design strategies, and urban design. Academically, Ahmad works as Assistant Dean for communication with industry and training. In Addition to his academic profession, Ahmad had worked on the architectural design, construction, and supervision in both United Arab Emirates and Jordan.

SAFA AL HUSBAN (safaalhusban@yahoo.com) is an assistant professor at the department of Architectural Engineering, at the Faculty of Engineering in $\mathrm{Al}$ alBayt University, Jordan. Safa got her PhD - DDes program (Doctor of Architectural Design) from the Interdisciplinary design institute at Washington State University in USA at 2012 with GPA (3.95). Her Dissertation topic is "Architectural Design of Plazas, Social Capital and Connectivity, and Cultural Hybridity in Neighborhoods: Defining a Multi-dimensional Social Network Model for Public Health Promotion". She got her Master degree in Architectural studies at 2007 from Jordan University of Science and Technology; the topic of her master thesis is: Assessment of the Residential Subdivision Practice in Jordan on the Light of Conceptual Sustainable Neighborhood Layout; and her Bachelor degree in Architectural engineering from Jordan University of Science and Technology at 1994. Academically, she worked as Dean Assistant for quality assurance at the Engineering Faculty at Al Al-Bayt University in 2015; 
Dean Assistant for students' affairs in 2013; and a Chair of the architectural engineering department at Al Al-Bayt University in 2014.

YAMEN AL-BETAWI (yamen_n@yahoo.com) is an architect and urban planner. $\mathrm{He}$ is currently an assistant professor at the Department of Architecture - The Hashemite University in Jordan. He holds a PhD in City and Regional Planning (2013) from Cardiff University, UK, a Masters degree in Urban Design (2004) from Jordan University of Science and Technology, and a Bachelor degree in Architecture (2001) also from Jordan University of Science and Technology. His research interests revolves around issues related to both the architectural and urban scale among which are place making, place identity, design of good cities, urban morphology, housing quality and residential satisfaction, planning and design processes, sustainable development, environmental design and quality of life. In addition to his academic profession, Yamen had worked on the design and consultation of several architecture, landscape and urban design and planning projects on both the local and regional scales, some of which were award-winning projects. 


\title{
Implementing the competences-based and student-centered learning approach in Architectural Design Education. The case of the T MEDA Pilot Architectural Program at the Hashemite University (Jordan)
}

\author{
Ahmad A. S. Al Husban, Safa A. M. Al Husban, and Yamen Al Betawi*
}

\section{Copyright}

Copyright for this article is retained by the Publisher. It is an Open Access material that is free for download, distribution, and or reuse in any medium only for non-commercial purposes; provided any applicable legislation is respected, the original work is properly cited, and any changes to the original are clearly indicated. 